\title{
Mechanochemical Reactions of Bis(9-methylphenyl-9-fluorenyl) Peroxides and their Applications in Cross-Linked Polymers
}

\author{
Yi Lu, Hajime Sugita, Koichiro Mikami, Daisuke Aoki, and Hideyuki Otsuka*
}

Department of Chemical Science and Engineering, Tokyo Institute of Technology, 2-12-1 Ookayama, Meguro-ku, Tokyo 152-8550, Japan. Fax: +81-3-5734-2131. E-mail: otsuka@mac.titech.ac.jp

Table of Contents

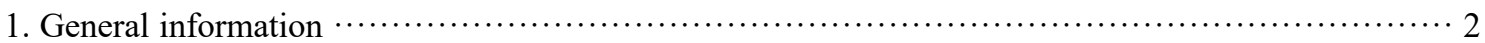

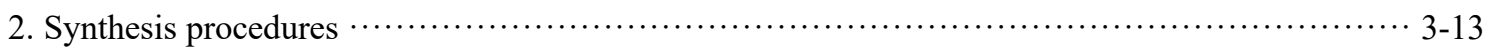

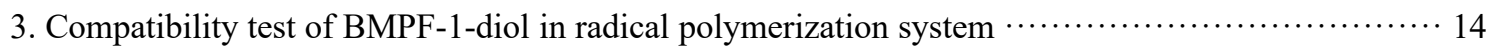

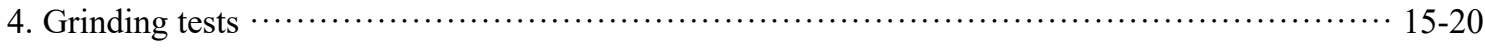

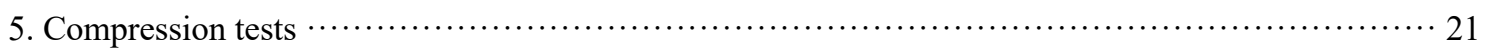

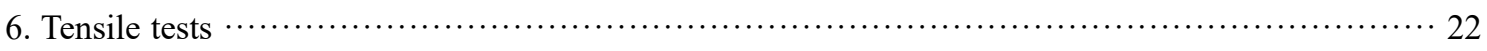

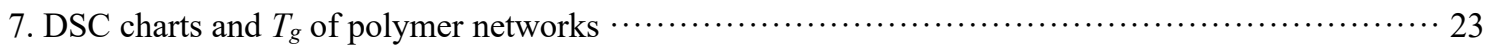

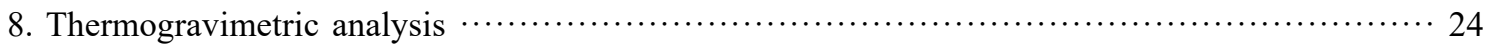

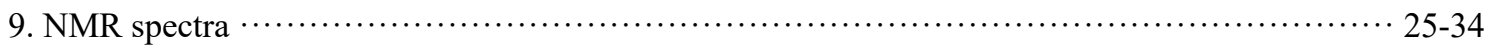

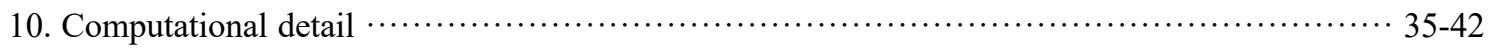

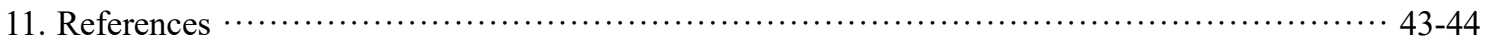




\section{General Information}

All reagents and solvents were purchased from Sigma-Aldrich, Wako Pure Chemical Industries, Tokyo Chemical Industry, or Kanto Chemical, and used as received, unless otherwise noted. Butyl methacrylate and hexyl methacrylate were filtrated by aluminum oxide 90 active basic before use. ${ }^{1} \mathrm{H}$ NMR spectra were obtained using a $500 \mathrm{MHz}$ Bruker spectrometer. ${ }^{13} \mathrm{C}$ NMR spectra were obtained using a $400 \mathrm{MHz}$ JNMECZ400S/L1 JEOL spectrometer or a $500 \mathrm{MHz}$ Bruker spectrometer. High-performance liquid chromatography (HPLC) analysis was performed at $30^{\circ} \mathrm{C}$ on a Shimadzu LC-20AD pump equipped with a guard column (YMC-Guardpack SIL), an analysis column (YMC-Triart C18), and an SPD-20A variable wavelength detector. Fluorescence measurements were carried out using a spectrofluorometer (JASCO FP6500 or JASCO FP8550). The UV-Vis absorption spectra were measured with a JASCO V-650 spectrometer. Stress relaxation measurements were carried out using Hitachi High-Tech Science TMA7100 under $\mathrm{N}_{2}$ flow. 


\section{Synthetic procedures}

2.1 Synthesis of BMPF-1-diol

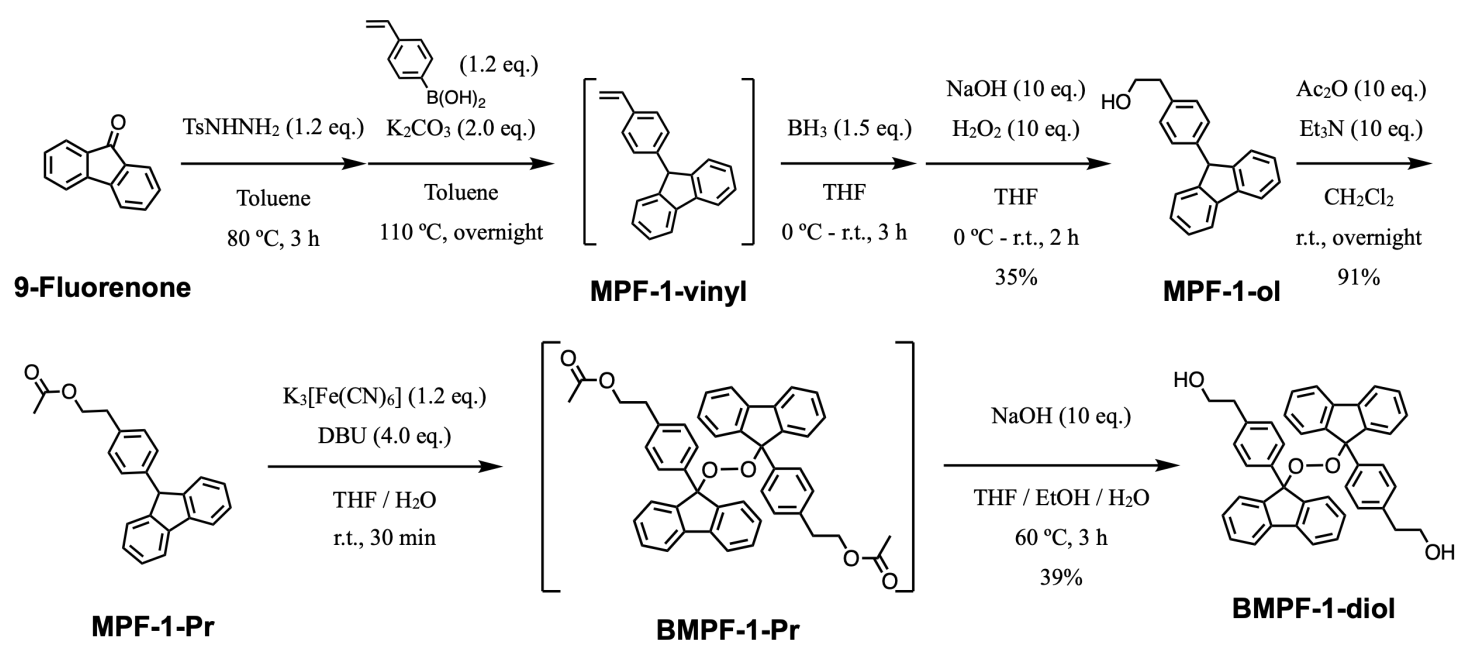

Scheme S1. Synthesis of BMPF-1-diol.

\section{MPF-1-vinyl}

The synthesis of 9-aryl-9H-fluorene was referred from the work of Liu et al. ${ }^{1}$

9-Fluorenone (1.1 g, $6.2 \mathrm{mmol})$ and $p$-toluenesulfonyl hydrazide (TsNHNH 2$)(1.4 \mathrm{~g}, 7.5 \mathrm{mmol}, 1.2 \mathrm{eq}$.) were mixed in $50 \mathrm{~mL}$ of dry toluene under inert atmosphere and heated to $80^{\circ} \mathrm{C}$. After heating for $3 \mathrm{~h}$, to the mixture was added $\mathrm{K}_{2} \mathrm{CO}_{3}(1.7 \mathrm{~g}, 12.4 \mathrm{mmol}, 2.0$ eq.) and 4-vinylphenylboronic acid (1.1 g, $7.5 \mathrm{mmol}$, 1.2 eq.). The resulting mixture was heated at $110^{\circ} \mathrm{C}$ overnight and then cooled down to room temperature. The resultant was diluted with EtOAc, washed with saturate $\mathrm{NaCl}$ aqueous solution in a separate funnel. The organic layer was collected, dried upon anhydrous $\mathrm{MgSO}_{4}$, and concentrated in vacuum to produce a pale-yellow crude residue MPF-1-vinyl which was used in the next step without further purification.

\section{MPF-1-ol}

Crude MPF-1-vinyl from the previous step was dissolved in $50 \mathrm{~mL}$ of dry THF and cooled down to $0{ }^{\circ} \mathrm{C}$. With vigorous stirring, to the solution was added THF solution of $\mathrm{BH}_{3} \cdot \mathrm{THF}$ complex $(10 \mathrm{~mL}, 0.9 \mathrm{M}, 9.3$ mmol, 1.5 eq.) under inert atmosphere. The mixture was allowed to warm up to room temperature and react for $3 \mathrm{~h}$. In the next, the resultant was cooled down to $0{ }^{\circ} \mathrm{C}$ and quenched by slow addition of cold water. Then, to the mixture was added $\mathrm{NaOH}\left(2.5 \mathrm{~g}, 62 \mathrm{mmol}, 10 \mathrm{eq}\right.$.) aqueous solution and $\mathrm{H}_{2} \mathrm{O}_{2}$ aqueous solution $(6.0 \mathrm{~g}, 35 \% \mathrm{w} / \mathrm{w}, 62 \mathrm{mmol}, 10 \mathrm{eq}$.). The mixture was stirred at room temperature for another $2 \mathrm{~h}$. The organic layer was diluted with EtOAc, washed with saturate $\mathrm{NaCl}$ aqueous solution in a separate funnel, dried upon anhydrous $\mathrm{MgSO}_{4}$, concentrated, and finally purified with column chromatography (silica gel, EtOAc/hexane = 1/3, v/v) to give MPF-1-ol a white solid ( $620 \mathrm{mg}, 2.2 \mathrm{mmol}, 35 \%$ for 2 steps).

${ }^{1} \mathrm{H}-\mathrm{NMR}$ (500 MHz, DMSO- $\left.d_{6}\right): \delta / \mathrm{ppm} 7.93$ (d, $\left.J=7.58 \mathrm{~Hz}, 2 \mathrm{H}\right), 7.36-7.44(\mathrm{~m}, 2 \mathrm{H}), 7.25-7.33(\mathrm{~m}, 4 \mathrm{H})$, 
$7.12(\mathrm{~d}, J=8.03 \mathrm{~Hz}, 2 \mathrm{H}), 6.97(\mathrm{~d}, J=8.04 \mathrm{~Hz}, 2 \mathrm{H}), 5.17(\mathrm{~s}, 1 \mathrm{H}), 4.61(\mathrm{t}, J=5.17 \mathrm{~Hz}, 1 \mathrm{H}), 3.58(\mathrm{q}, J=$ $6.40 \mathrm{~Hz}, 2 \mathrm{H}), 2.67(\mathrm{t}, J=7.05 \mathrm{~Hz}, 2 \mathrm{H})$.

${ }^{13}$ C-NMR (125 MHz, DMSO-d6): $\delta / p p m ~ 148.12,140.87,139.38,138.43,129.67,128.19,127.82,127.78$, $125.67,120.60,62.52,53.52,39.11$.

FAB-MS (m/z): [M+] calcd. for $\mathrm{C}_{21} \mathrm{H}_{18} \mathrm{O}$ : 286.1358; Found, 286.1361.

\section{MPF-1-Pr}

MPF-1-ol $(600 \mathrm{mg}, 2.1 \mathrm{mmol})$ was dissolved in $10 \mathrm{~mL}$ of dry $\mathrm{CH}_{2} \mathrm{Cl}_{2}$ at room temperature. To the solution was added $\mathrm{Et}_{3} \mathrm{~N}$ (2.9 mL, $2.1 \mathrm{~g}, 21 \mathrm{mmol}, 10$ eq.) and then $\mathrm{Ac}_{2} \mathrm{O}$ (1.9 mL, $2.1 \mathrm{~g}, 21 \mathrm{mmol}, 10$ eq.). The mixture was stirred at room temperature overnight and then quenched by the addition of excess amount of $\mathrm{MeOH}$. The resultant was concentrated, diluted with EtOAc, and washed with saturate $\mathrm{NaHCO}_{3}$ aqueous solution. The organic layer was collected, dried upon anhydrous $\mathrm{MgSO}_{4}$, concentrated in vacuum, and purified with column chromatography ( solid (630 mg, $1.9 \mathrm{mmol}, 91 \%)$.

${ }^{1} \mathrm{H}-\mathrm{NMR}$ (500 MHz, DMSO-d6): $\delta / \mathrm{ppm} 7.93$ (d, $\left.J=7.56 \mathrm{~Hz}, 2 \mathrm{H}\right), 7.36-7.44$ (m, 2H), 7.23-7.32 (m, 4H), $7.16(\mathrm{~d}, J=8.08 \mathrm{~Hz}, 2 \mathrm{H}), 7.00(\mathrm{~d}, J=8.04 \mathrm{~Hz}, 2 \mathrm{H}), 5.17(\mathrm{~s}, 1 \mathrm{H}), 4.18(\mathrm{t}, J=6.98 \mathrm{~Hz}, 2 \mathrm{H}), 2.84(\mathrm{t}, J=6.97$ $\mathrm{Hz}, 2 \mathrm{H}), 1.98(\mathrm{~s}, 3 \mathrm{H})$.

${ }^{13} \mathrm{C}-\mathrm{NMR}$ (125 MHz, DMSO-d6): $\delta / \mathrm{ppm} 170.76,148.01,140.88,140.00,136.83,129.62,128.43,127.84$, $127.81,125.65,120.61,64.74,53.48,34.39,21.19$.

FAB-MS $(\mathrm{m} / \mathrm{z}):\left[\mathrm{M}^{+}\right]$calcd. for $\mathrm{C}_{23} \mathrm{H}_{20} \mathrm{O}_{2}: 328.1463$; Found, 328.1470 .

\section{BMPF-1-Pr}

MPF-1-Pr (1.0 g, $3.1 \mathrm{mmol})$ and $\mathrm{K}_{3}\left[\mathrm{Fe}(\mathrm{CN})_{6}\right]\left(1.2 \mathrm{~g}, 3.7 \mathrm{mmol}, 1.2\right.$ eq.) were mixed in $\mathrm{THF} / \mathrm{H}_{2} \mathrm{O}(40$ $\mathrm{mL} / 10 \mathrm{~mL}$ ) mixed solvent at room temperature. To the mixture was added 1,8-diazabicyclo[5.4.0]undec-7ene (DBU) (1.9 g, $1.9 \mathrm{~mL}, 12 \mathrm{mmol}, 4.0$ eq.) dropwise and the resultant was stirred at room temperature for 30 minutes. Then, the organic layer was diluted with EtOAc, washed with saturate $\mathrm{NaCl}$ aqueous solution, concentrated, dried upon anhydrous $\mathrm{MgSO}_{4}$, and purified with column chromatography (silica gel, EtOAc/hexane $=1 / 4, \mathrm{v} / \mathrm{v}$ ) to give BMPF-1-Pr as a red solid with a small number of impurities, which was further removed in the next step.

\section{BMPF-1-diol}

BMPF-1-Pr derived from the previous step was dissolved in THF/EtOH/ $\mathrm{H}_{2} \mathrm{O}(30 \mathrm{~mL} / 10 \mathrm{~mL} / 10 \mathrm{~mL})$ mixed solvent. To the solution was added $\mathrm{NaOH}\left(1.2 \mathrm{~g}, 31 \mathrm{mmol}, 10\right.$ eq.). The resultant was heated to $60{ }^{\circ} \mathrm{C}$ for 2 hours and then cooled down to room temperature. The organic layer was diluted with EtOAc, washed with saturate $\mathrm{NaCl}$ aqueous solution, concentrated, dried upon anhydrous $\mathrm{MgSO}_{4}$, and purified with column chromatography (silica gel, EtOAc/hexane = 3/1, v/v) to afford a white solid BMPF-1-diol (360 mg, 1.6 
mmol, 39\%).

${ }^{1} \mathrm{H}-\mathrm{NMR}\left(500 \mathrm{MHz}, \mathrm{DMSO}-d_{6}\right): \delta / \mathrm{ppm} 7.80(\mathrm{~d}, J=7.55 \mathrm{~Hz}, 2 \mathrm{H}), 7.40(\mathrm{t}, J=7.23 \mathrm{~Hz}, 2 \mathrm{H}), 7.22(\mathrm{t}, J=$ $7.50 \mathrm{~Hz}, 2 \mathrm{H}), 7.15$ (d, $J=7.45 \mathrm{~Hz}, 2 \mathrm{H}), 7.03$ (d, $J=8.03 \mathrm{~Hz}, 2 \mathrm{H}), 6.96$ (d, $J=8.25,2 \mathrm{H}), 4.55$ (t, $J=5.13$ $\mathrm{Hz}, 1 \mathrm{H}), 3.52(\mathrm{q}, J=6.29 \mathrm{~Hz}, 2 \mathrm{H}), 2.60(\mathrm{t}, J=6.93 \mathrm{~Hz}, 2 \mathrm{H})$.

${ }^{13} \mathrm{C}-\mathrm{NMR}$ (125 MHz, DMSO-d $d_{6}$ : $\delta /$ ppm 145.73, 140.43, 139.68, 138.25, 129.89, 129.30, 128.21, 126.29 , $125.93,120.84,93.17,62.26,38.98,30.07$.

ESI-TOF-MS $(\mathrm{m} / \mathrm{z})$ : $[\mathrm{M}+\mathrm{Na}]^{+}$calcd. for $\mathrm{C}_{43} \mathrm{H}_{34} \mathrm{O}_{4} \mathrm{Na}$ : 625.235480; Found, 625.234930 . 


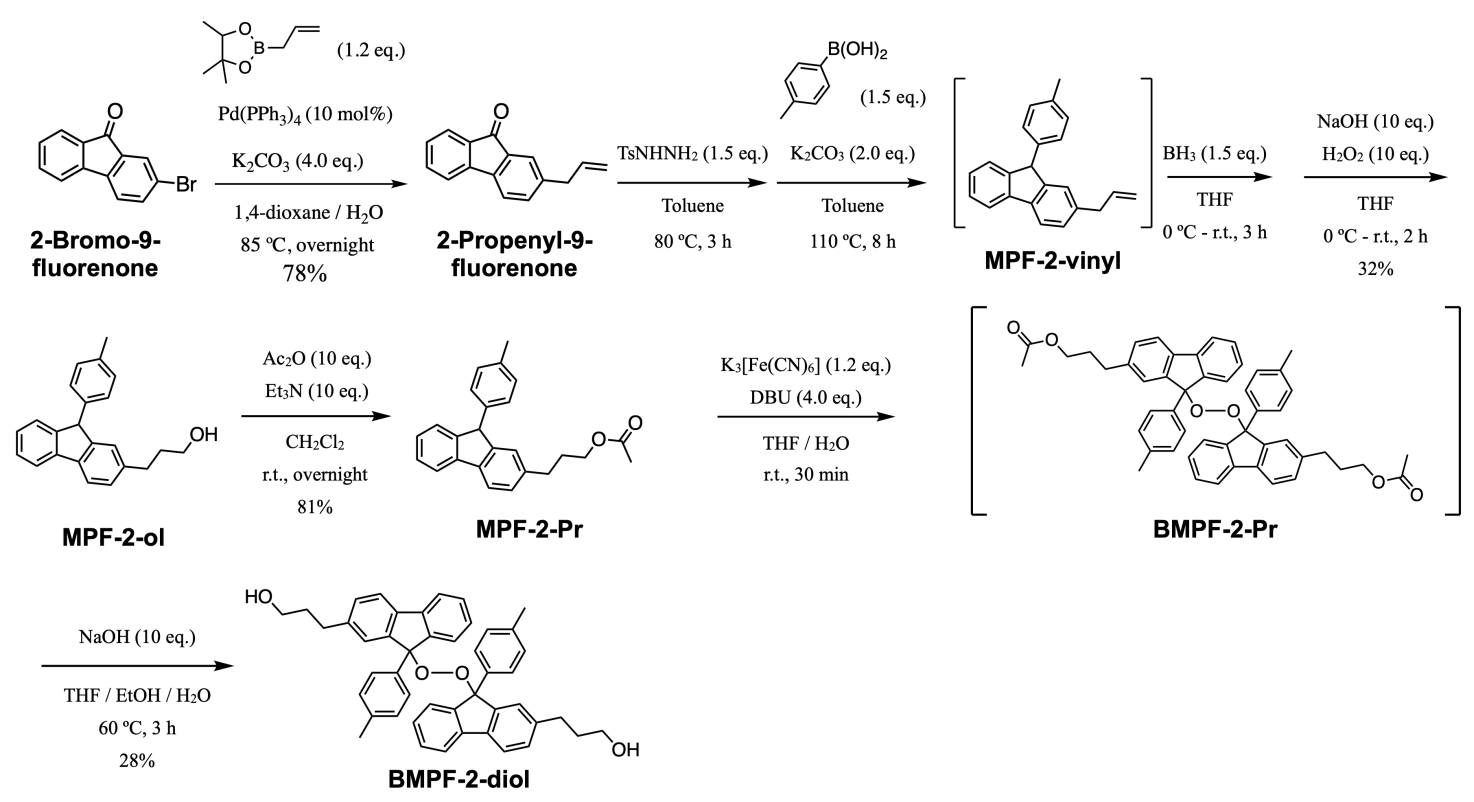

Scheme S2. Synthesis of BMPF-2-diol.

\section{2-Propenyl-9-fluorenone}

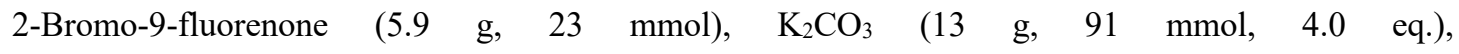
tetrakis(triphenylphosphine)palladium(0) (1.8 g, $1.6 \mathrm{mmol}, 7 \mathrm{~mol} \%)$, and 2-allyl-4,4,5,5-tetramethyl-1,3,2dioxaborolane (5.0 g, $30 \mathrm{mmol}, 1.3 \mathrm{eq}$.) were mixed in 1,4-dioxane $/ \mathrm{H}_{2} \mathrm{O}(80 \mathrm{~mL} / 20 \mathrm{~mL})$ mixed solvent at room temperature under inert atmosphere. The mixture was heated to $85{ }^{\circ} \mathrm{C}$ overnight and then cooled down to room temperature. The organic layer was diluted with EtOAc, washed with a saturated $\mathrm{NaCl}$ aqueous solution, concentrated, dried upon anhydrous $\mathrm{MgSO}_{4}$, and purified with column chromatography (silica gel, hexane/dichloromethane $=4 / 1, \mathrm{v} / \mathrm{v}$ ) to afford 2-propenyl-9-fluorenone as a yellow solid $(3.9 \mathrm{~g}$, $18 \mathrm{mmol}, 78 \%)$.

${ }^{1} \mathrm{H}-\mathrm{NMR}\left(500 \mathrm{MHz}\right.$, DMSO- $\left.d_{6}\right): \delta / \mathrm{ppm} 7.74(\mathrm{~d}, J=7.15 \mathrm{~Hz}, 1 \mathrm{H}), 7.71(\mathrm{~d}, J=8.20 \mathrm{~Hz}, 1 \mathrm{H}), 7.57-7.62(\mathrm{~m}$, $2 \mathrm{H}), 7.40-7.44(\mathrm{~m}, 2 \mathrm{H}), 7.35(\mathrm{t}, J=7.45 \mathrm{~Hz}, 1 \mathrm{H}), 5.93-6.03(\mathrm{~m}, 1 \mathrm{H}), 5.07-5.20(\mathrm{~m}, 2 \mathrm{H}), 3.42$ (d, $J=6.75$ $\mathrm{Hz}, 2 \mathrm{H})$.

${ }^{13} \mathrm{C}-\mathrm{NMR}$ (125 MHz, DMSO-d6): $\delta / \mathrm{ppm} 193.63,144.42,142.37,142.05,137.47,135.79,135.68,134.10$, $133.86,129.58,124.41,124.34,121.64,121.41,116.93$.

FAB-MS (m/z): [M+H] $]^{+}$calcd. for $\mathrm{C}_{16} \mathrm{H}_{13} \mathrm{O}$ : 221.096640; Found, 221.0963.

\section{MPF-2-vinyl}

2-Propenyl-9-fluorenone $(2.0 \mathrm{~g}, 9.1 \mathrm{mmol})$ and $\mathrm{TsNHNH}_{2}(2.5 \mathrm{~g}, 14 \mathrm{mmol}, 1.5$ eq.) were mixed in 80 $\mathrm{mL}$ of dry toluene under inert atmosphere and heated to $80^{\circ} \mathrm{C}$. After heating for $3 \mathrm{~h}$, to the mixture was added $\mathrm{K}_{2} \mathrm{CO}_{3}$ (2.5 g, $18 \mathrm{mmol}, 2.0$ eq.) and 4-methylphenylboronic acid (1.9 g, $14 \mathrm{mmol}, 1.5$ eq.). The 
resulting mixture was heated at $110^{\circ} \mathrm{C}$ for 8 hours and then cooled down to room temperature. The resultant was diluted with EtOAc, washed with saturate $\mathrm{NaCl}$ aqueous solution in a separate funnel. The organic layer was collected, dried upon anhydrous $\mathrm{MgSO}_{4}$, and concentrated in vacuum to produce a pale-yellow crude residue MPF-2-vinyl which was used in the next step without further purification.

\section{MPF-2-ol}

Crude MPF-2-vinyl from the previous step was dissolved in $80 \mathrm{~mL}$ of dry THF and cooled down to $0^{\circ} \mathrm{C}$. With vigorous stirring, to the solution was added THF solution of $\mathrm{BH}_{3} \cdot$ THF complex (15 mL, $0.9 \mathrm{M}, 14$ mmol, 1.5 eq.) under inert atmosphere. The mixture was allowed to warm up to room temperature and react for $3 \mathrm{~h}$. In the next, the resultant was cooled down to $0^{\circ} \mathrm{C}$ and quenched by slow addition of cold water. Then, to the mixture was added $\mathrm{NaOH}\left(3.6 \mathrm{~g}, 91 \mathrm{mmol}, 10\right.$ eq.) aqueous solution and $\mathrm{H}_{2} \mathrm{O}_{2}$ aqueous solution $(9.0 \mathrm{~g}, 35 \% \mathrm{w} / \mathrm{w}, 92 \mathrm{mmol}, 10 \mathrm{eq}$.). The mixture was stirred at room temperature for another $2 \mathrm{~h}$. The organic layer was diluted with EtOAc, washed with saturate $\mathrm{NaCl}$ aqueous solution in a separate funnel, dried upon anhydrous $\mathrm{MgSO}_{4}$, concentrated, and finally purified with column chromatography (silica gel, EtOAc/hexane = 1/3, v/v) to give MPF-1-ol as a white solid ( $910 \mathrm{mg}, 2.9 \mathrm{mmol}, 32 \%$ for 2 steps).

${ }^{1} \mathrm{H}-\mathrm{NMR}\left(500 \mathrm{MHz}\right.$, DMSO- $\left.d_{6}\right): \delta / \mathrm{ppm} 7.86(\mathrm{~d}, J=7.55 \mathrm{~Hz}, 1 \mathrm{H}), 7.81(\mathrm{~d}, J=7.76 \mathrm{~Hz}, 1 \mathrm{H}), 7.36(\mathrm{~m}, 1 \mathrm{H})$, $7.20-7.25$ (m, 3H), 7.06-7.11 (m, 3H), 6.94 (d, $J=7.99 \mathrm{~Hz}, 2 \mathrm{H}), 5.11(\mathrm{~s}, 1 \mathrm{H}), 4.43(\mathrm{t}, J=5.14 \mathrm{~Hz}, 1 \mathrm{H})$, 3.39 (q, $J=5.95 \mathrm{~Hz}, 2 \mathrm{H}), 2.61(\mathrm{t}, J=7.70 \mathrm{~Hz}, 2 \mathrm{H}), 2.25$ (s, 1H), 1.69 (m, 2H).

${ }^{13} \mathrm{C}-\mathrm{NMR}$ (125 MHz, DMSO-d6): $\delta / \mathrm{ppm} 148.43,148.13,142.16,140.95,139.06,138.55,136.20,129.72$, 128.36, 127.94, 127.69, 127.34, 125.53, 125.42, 120.37, 120.23, 60.54, 53.43, 34.99, 32.21, 21.10.

FAB-MS $(\mathrm{m} / \mathrm{z})$ : $\left[\mathrm{M}^{+}\right]$calcd. for $\mathrm{C}_{23} \mathrm{H}_{22} \mathrm{O}: 314.1671$; Found, 314.1668 .

\section{MPF-2-Pr}

MPF-2-ol (900 mg, $2.9 \mathrm{mmol}$ ) was dissolved in $25 \mathrm{~mL}$ of dry $\mathrm{CH}_{2} \mathrm{Cl}_{2}$ at room temperature. To the solution was added $\mathrm{Et}_{3} \mathrm{~N}$ (4.0 mL, $2.9 \mathrm{~g}, 29 \mathrm{mmol}, 10$ eq.) and then $\mathrm{Ac}_{2} \mathrm{O}(2.6 \mathrm{~mL}, 2.9 \mathrm{~g}, 29 \mathrm{mmol}, 10$ eq.). The mixture was stirred at room temperature overnight and then quenched by the addition of excess amount of $\mathrm{MeOH}$. The resultant was concentrated, diluted with EtOAc and washed with saturate $\mathrm{NaHCO}_{3}$ aqueous solution. The organic layer was collected, dried upon anhydrous $\mathrm{MgSO}_{4}$, concentrated in vacuum and purified with column chromatography (silica gel, EtOAc/hexane $=1 / 9, \mathrm{v} / \mathrm{v}$ ) to give MPF-2-Pr as a white solid (840 mg, $2.3 \mathrm{mmol}, 81 \%$ ).

${ }^{1} \mathrm{H}-\mathrm{NMR}$ (500 MHz, DMSO-d6): $\delta / \mathrm{ppm} 7.88(\mathrm{~d}, J=7.58 \mathrm{~Hz}, 1 \mathrm{H}), 7.83(\mathrm{~d}, J=7.76 \mathrm{~Hz}, 1 \mathrm{H}), 7.32-7.41(\mathrm{~m}$, 1H), 7.20-7.28 (m, 3H), 7.05-7.13 (m, 3H), 6.94 (d, $J=7.99 \mathrm{~Hz}, 2 \mathrm{H}), 5.11(\mathrm{~s}, 1 \mathrm{H}), 3.98$ (t, $J=6.66 \mathrm{~Hz}$, $2 \mathrm{H}), 2.64(\mathrm{q}, J=7.72 \mathrm{~Hz}, 2 \mathrm{H}), 2.25$ (s, 3H), 1.98 (s, 3H), 1.77-1.92 (m, 2H).

${ }^{13} \mathrm{C}-\mathrm{NMR}$ (125 MHz, DMSO- $\left.d_{6}\right): \delta / \mathrm{ppm} 170.85,148.50,148.16,141.12,140.85,138.99,138.83,136.21$, $129.73,128.36,127.93,127.71,127.42,125.53,125.44,120.47,120.30,63.70,53.44,32.02,30.40,21.13$, 21.09 . 
FAB-MS $(\mathrm{m} / z):\left[\mathrm{M}^{+}\right]$calcd. For $\mathrm{C}_{25} \mathrm{H}_{24} \mathrm{O}_{2}: 356.1776$; Found, 356.1784.

\section{BMPF-2-Pr}

MPF-2-Pr $(600 \mathrm{mg}, 1.7 \mathrm{mmol}), \mathrm{K}_{3}\left[\mathrm{Fe}(\mathrm{CN})_{6}\right]\left(720 \mathrm{mg}, 2.2 \mathrm{mmol}, 1.2\right.$ eq.) were mixed in $\mathrm{THF} / \mathrm{H}_{2} \mathrm{O}(20$ $\mathrm{mL} / 5 \mathrm{~mL})$ mixed solvent at room temperature. To the mixture was added DBU (1.0 g, $1.0 \mathrm{~mL}, 6.7 \mathrm{mmol}$, 4.0 eq.) dropwise and the resultant was stirred at room temperature for 30 minutes. In the next, the organic layer was diluted with EtOAc, washed with a saturated $\mathrm{NaCl}$ aqueous solution, concentrated, dried upon anhydrous $\mathrm{MgSO}_{4}$, and purified with column chromatography ( BMPF-2-Pr as a red solid with a small number of impurities, which was further removed in the next step.

\section{BMPF-2-diol}

BMPF-2-Pr derived from the previous step was dissolved in THF/EtOH/ $\mathrm{H}_{2} \mathrm{O}(15 \mathrm{~mL} / 5 \mathrm{~mL} / 5 \mathrm{~mL})$ mixed solvent. To the solution was added $\mathrm{NaOH}\left(640 \mathrm{mg}, 16 \mathrm{mmol}, 10\right.$ eq.). The resultant was heated to $60{ }^{\circ} \mathrm{C}$ and then cooled down to room temperature. The organic layer was diluted with EtOAc, washed with a saturated $\mathrm{NaCl}$ aqueous solution, concentrated, dried upon anhydrous $\mathrm{MgSO}_{4}$, purified with column chromatography ( a white solid BMPF-2-diol (160 mg, $1.6 \mathrm{mmol}, 28 \%$ ).

Note: Obtained BMPF-2-diol was a mixture of two isomers, which cannot be separated by silica column or preparative GPC.

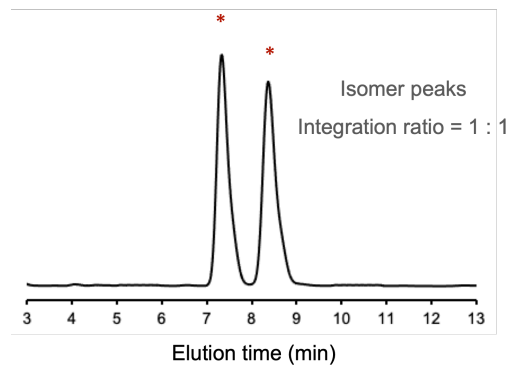

Figure S1. HPLC analysis of BMPF-2-diol $\left(\mathrm{CH}_{3} \mathrm{CN} / \mathrm{H}_{2} \mathrm{O}=80 / 20\right)$.

${ }^{1} \mathrm{H}-\mathrm{NMR}\left(500 \mathrm{MHz}, \mathrm{DMSO}-d_{6}\right): \delta / \mathrm{ppm} 7.74(\mathrm{t}, J=7.50 \mathrm{~Hz}, 1 \mathrm{H}), 7.69$ (t, $\left.J=7.78 \mathrm{~Hz}, 1 \mathrm{H}\right), 7.32-7.42$ (m, 1H), 7.06-7.27 (m, 3H), 6.90-7.03 (m, 5H), 4.42-4.50 (m, 1H), 3.38-3.47 (m, 2H), 2.55-2.63 (m, 2H), $2.18(\mathrm{~s}, 3 \mathrm{H}), 1.57-1.73(\mathrm{~m}, 2 \mathrm{H})$.

${ }^{13} \mathrm{C}-\mathrm{NMR}$ (125 MHz, DMSO-d6): $\delta / \mathrm{ppm}$ 146.07, 145.62, 142.44, 140.52, 140.47, 138.21, 137.98, 137.91, $137.37,129.28,126.44,126.17,126.13,125.99$, 120.64, 120.59, 120.53, 93.07, 60.56, 34.82, 32.19, 21.00. ESI-TOF-MS (m/z): [M+Na] $]^{+}$calcd. for $\mathrm{C}_{46} \mathrm{H}_{42} \mathrm{O}_{4} \mathrm{Na}$ : 681.298080; Found, 681.297531. 
2.3 Syntheses of vinyl-type cross-linkers

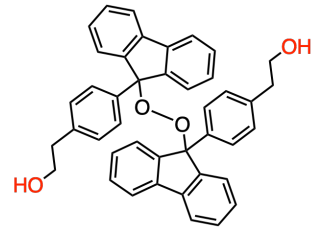

BMPF-1-diol

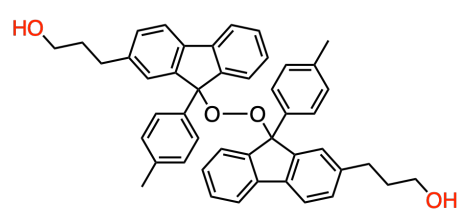

BMPF-2-diol

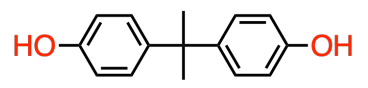

BPA

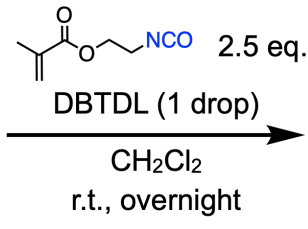

$92 \%$

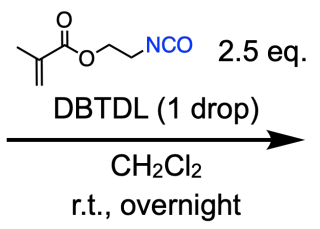

$87 \%$

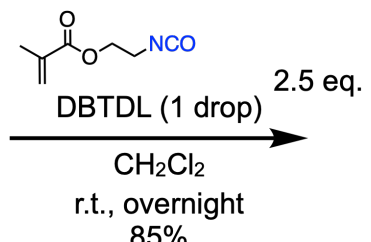

$85 \%$

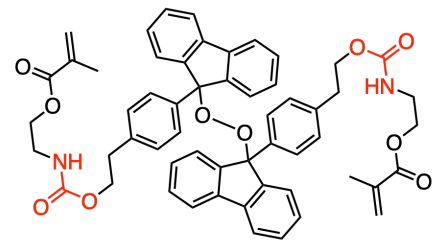

BMPF-1-VCL

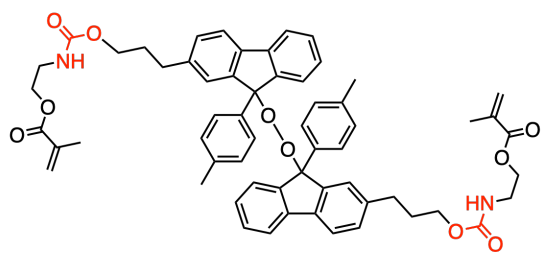

BMPF-2-VCL

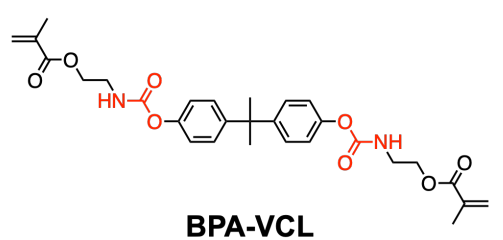

Scheme S3. Syntheses of vinyl-type cross-linkers.

As a general method, diol and 2-isocyanatoethyl methacrylate (2.5 eq) were dissolved in dry $\mathrm{CH}_{2} \mathrm{Cl}_{2}$ under inert atmosphere at room temperature. One drop of DBTDL was added to the mixture and then the mixture was stirred at room temperature overnight. The resultant was concentrated in vacuum and purified with column chromatography (silica gel, EtOAc/hexane $=1 / 3-1 / 2$ ) to give white solids as the products.

BMPF-1-VCL (yield = 92\%)

${ }^{1} \mathrm{H}-\mathrm{NMR}\left(500 \mathrm{MHz}, \mathrm{CDCl}_{3}\right) \delta / \mathrm{ppm} 7.58(\mathrm{~d}, J=7.49 \mathrm{~Hz}, 2 \mathrm{H}), 7.29$ (t, $\left.J=7.40 \mathrm{~Hz}, 2 \mathrm{H}\right), 7.04-7.16(\mathrm{~m}, 6 \mathrm{H})$, $6.99(\mathrm{~d}, J=8.12 \mathrm{~Hz}, 2 \mathrm{H}), 6.08(\mathrm{~s}, 1 \mathrm{H}), 5.55(\mathrm{~s}, 1 \mathrm{H}), 4.88(\mathrm{~s}, 1 \mathrm{H}), 4.11-4.30(\mathrm{~m}, 4 \mathrm{H}), 3.40-3.50(\mathrm{~m}, 2 \mathrm{H})$, $2.81(\mathrm{t}, J=6.75 \mathrm{~Hz}, 2 \mathrm{H}), 1.91(\mathrm{~s}, 3 \mathrm{H})$.

${ }^{13} \mathrm{C}-\mathrm{NMR}\left(100 \mathrm{MHz}, \mathrm{CDCl}_{3}\right): \delta / \mathrm{ppm} 167.33,156.44,146.04,140.67,139.21,137.00,136.02,129.10$, $128.67,127.58,126.49,126.33,126.12,119.74,93.14,65.37,63.77,40.20,35.14,18.41$.

BMPF-2-VCL (yield = 87\%)

${ }^{1} \mathrm{H}-\mathrm{NMR}\left(500 \mathrm{MHz}, \mathrm{CDCl}_{3}\right) \delta / \mathrm{ppm} 7.52(\mathrm{t}, J=8.55,1 \mathrm{H}), 7.40-7.49$ (m, 1H), 7.16-7.31 (m, 2H), 6.79$7.16(\mathrm{~m}, 7 \mathrm{H}), 6.11(\mathrm{~s}, 1 \mathrm{H}), 5.57(\mathrm{~s}, 1 \mathrm{H}), 4.85-5.14(\mathrm{~m}, 2 \mathrm{H}), 4.21(\mathrm{~s}, 2 \mathrm{H}), 3.98-4.13(\mathrm{~m}, 2 \mathrm{H}), 3.26-3.55(\mathrm{~m}$, $2 \mathrm{H}), 2.36-2.63(\mathrm{~m}, 2 \mathrm{H}), 2.25(\mathrm{~s}, 3 \mathrm{H}), 1.93(\mathrm{~s}, 3 \mathrm{H}), 1.67-1.88(\mathrm{~m}, 2 \mathrm{H})$. 
${ }^{13} \mathrm{C}-\mathrm{NMR}\left(125 \mathrm{MHz}, \mathrm{CDCl}_{3}\right)$ : $\delta / \mathrm{ppm} 167.30,156.58,146.45,146.08,140.47,140.40,138.68,138.15$, $136.95,135.98,129.01,128.98,128.82,127.22,127.12,126.78,126.52,126.25,126.15,126.10,119.32$, $93.09,64.61,63.73,53.81,40.14,32.19,31.74,30.49,29.29,21.08,18.32$.

BPA-VCL (yield $=85 \%$ )

${ }^{1} \mathrm{H}-\mathrm{NMR}$ (500 MHz, DMSO- $d_{6}$ ): $\delta / \mathrm{ppm} 7.90$ (t, $\left.J=5.75 \mathrm{~Hz}, 1 \mathrm{H}\right), 7.22(\mathrm{~d}, J=8.40 \mathrm{~Hz}, 2 \mathrm{H}), 7.00$ (d, $J=$ $8.40 \mathrm{~Hz}, 2 \mathrm{H}), 6.10$ (s, 1H), $5.70(\mathrm{~s}, 1 \mathrm{H}), 4.16$ (t, $J=5.28 \mathrm{~Hz}, 2 \mathrm{H}), 3.36$ (q, $J=5.54 \mathrm{~Hz}, 2 \mathrm{H}), 1.89$ (s, 3H), $1.64(\mathrm{~s}, 3 \mathrm{H})$.

${ }^{13} \mathrm{C}-\mathrm{NMR}$ (125 MHz, DMSO-d6): $\delta / \mathrm{ppm}$ 167.00, 155.10, 149.27, 147.20, 136.26, 127.74, 126.48, 121.60, 63.61, 42.30, 30.99, 18.45 . 
2.4 Syntheses of polymer networks

2.4.1 Syntheses of poly(butyl methacrylate) networks

A)

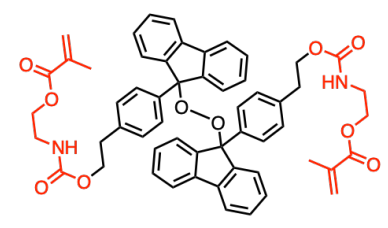

BMPF-1-VCL butyl methacrylate (99 eq.)

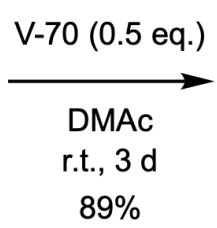

$89 \%$

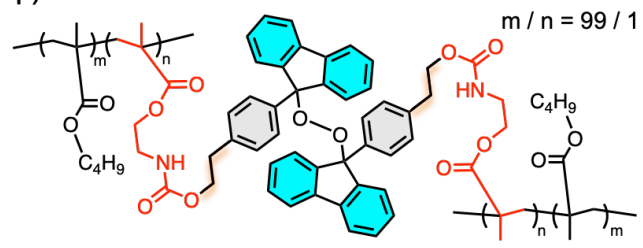

BMPF-1-PB

B)

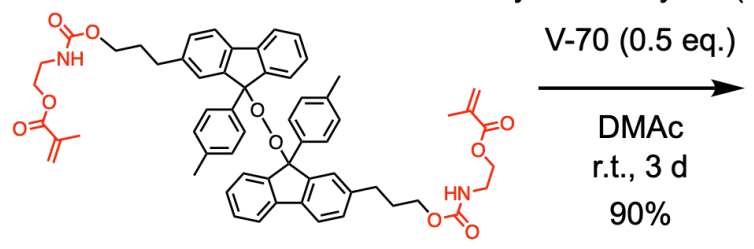

BMPF-2-VCL

butyl methacrylate (99 eq.)

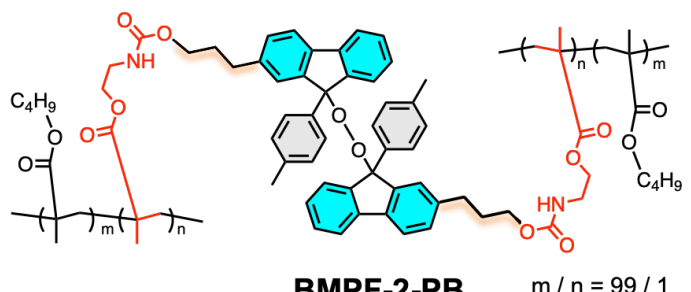

C)

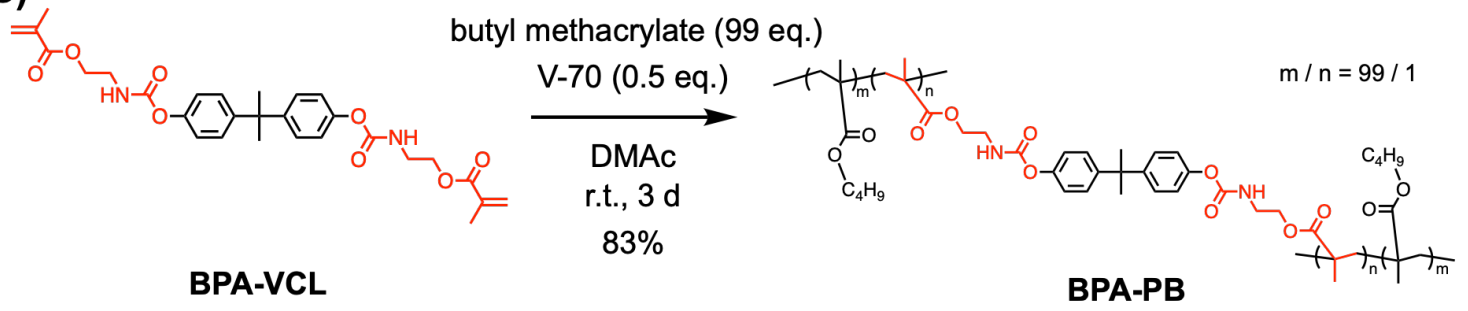

Scheme S4. Syntheses of poly(butyl methacrylate) networks.

As a general method, a vinyl type cross-linker and butyl methacrylate (99 eq.) were dissolved in proper amount of dry DMAc at room temperature. The mixture was bubbled with argon for 30 minutes. To the mixture was then added 2,2'-azobis(4-methoxy-2,4-dimethylvaleronitrile) (V-70) (0.5 eq.), followed by argon bubbling for another 1 minutes. The resulting mixture was injected via syringe into a glass mold in argon atmosphere, which was left for 72 hours at room temperature. The reaction was quenched by exposure to air. The obtained polymer film was washed with the mixture of chloroform/methanol (gradient from 3/1 to $1 / 3, \mathrm{v} / \mathrm{v}$ ) for 3 times. The washed film was dried at elevated temperature for 24 hours to afford a transparent colorless film. 
2.4.2 Syntheses of poly(hexyl methacrylate) networks

A)

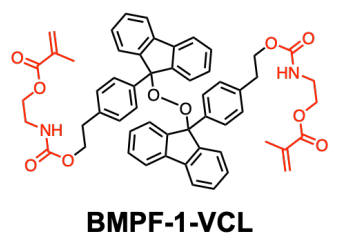

B)

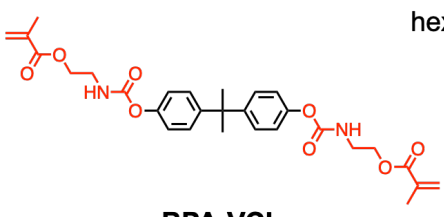

BPA-VCL

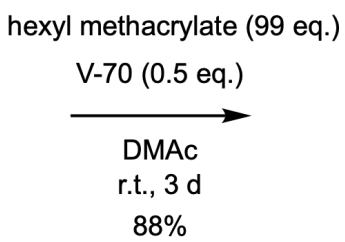

$88 \%$

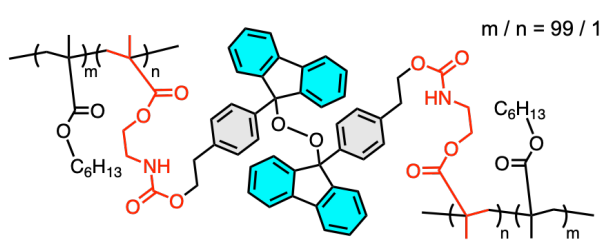

BMPF-1-PH hexyl methacrylate (99 eq.)

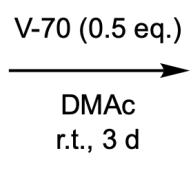

$85 \%$

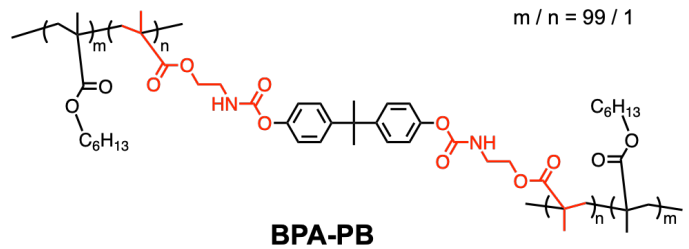

Scheme S5. Syntheses of poly(hexyl methacrylate) networks.

As a general method, a vinyl type cross-linker and hexyl methacrylate (99 eq.) were dissolved in proper amount of dry DMAc at room temperature. The mixture was bubbled with argon for 30 minutes. To the mixture was then added V-70 ( 0.5 eq.), followed by argon bubbling for another 1 minutes. The resulting mixture was injected via syringe into a glass mold in argon atmosphere, which was left for 72 hours at room temperature. The reaction was quenched by exposure to air. The obtained polymer film was washed with the mixture of chloroform/methanol (gradient from $3 / 1$ to $1 / 3, v / v$ ) for 3 times. The washed film was dried at elevated temperature for 24 hours to afford a transparent colorless film. 


\subsubsection{Swelling tests}

About $20 \mathrm{mg}$ of the dry polymer network was weighed and swollen in $\mathrm{MeOH}$, THF, or chloroform at room temperature. The swollen polymer was weighed for every 12 hours and the swelling ratio was calculated using the following equation:

$$
\text { Swelling degree }=\frac{W_{\text {gel }}-W_{d r y}}{W_{d r y}} \times 100 \%
$$

Obtained results were recorded in the following table:

Table S1. Swelling degrees of polymer networks

\begin{tabular}{cccc||cc}
\hline$\%$ & BMPF-1-PB & BPA-PB & BMPF-2-PB & BMPF-1-PH & BPA-PH \\
\hline $\mathrm{MeOH}$ & $30 \pm 9$ & $29 \pm 5$ & $32 \pm 5$ & $30 \pm 7$ & $31 \pm 7$ \\
$\mathrm{THF}$ & $701 \pm 24$ & $701 \pm 22$ & $716 \pm 51$ & $766 \pm 26$ & $771 \pm 27$ \\
$\mathrm{CHCl}_{3}$ & $1090 \pm 67$ & $1055 \pm 42$ & $1103 \pm 57$ & $1361 \pm 117$ & $1386 \pm 49$ \\
\hline
\end{tabular}




\section{Compatibility test of BMPF-1-diol in radical polymerization system}

\section{Condition A:}

To DMSO- $d_{6}$ was added BMPF-1-diol $(5.0 \mathrm{mg}, 0.0083 \mathrm{mmol})$, butyl methacrylate $(50 \mu \mathrm{L}, 45 \mathrm{mg}, 0.31$ $\mathrm{mmol}$ ), and AIBN (8.0 mg, $0.049 \mathrm{mmol}$ ) in order. The mixture was degassed and heated to $70{ }^{\circ} \mathrm{C}$ for 18 hours. ${ }^{1} \mathrm{H}$ NMR spectrum after the polymerization reaction and the pristine spectrum were shown in Figure S2 (A) and Figure S2 (C), respectively. No change was observed.

\section{Condition B:}

To DMSO- $d_{6}$ was added BMPF-1-diol $(5.0 \mathrm{mg}, 0.0083 \mathrm{mmol})$, butyl methacrylate $(30 \mu \mathrm{L}, 27 \mathrm{mg}, 0.19$ $\mathrm{mmol})$, and V-70 (8.0 mg, $0.026 \mathrm{mmol})$ in order. The mixture was degassed and stand for 3 days. ${ }^{1} \mathrm{H}$ NMR spectrum after 3 days and the pristine spectrum were shown in Figure S2(B) and Figure S2(C). No change was observed.

A) Polymerization of butyl methacrylate with AIBN, $70^{\circ} \mathrm{C}, 18 \mathrm{~h}$, DMSO-d 6

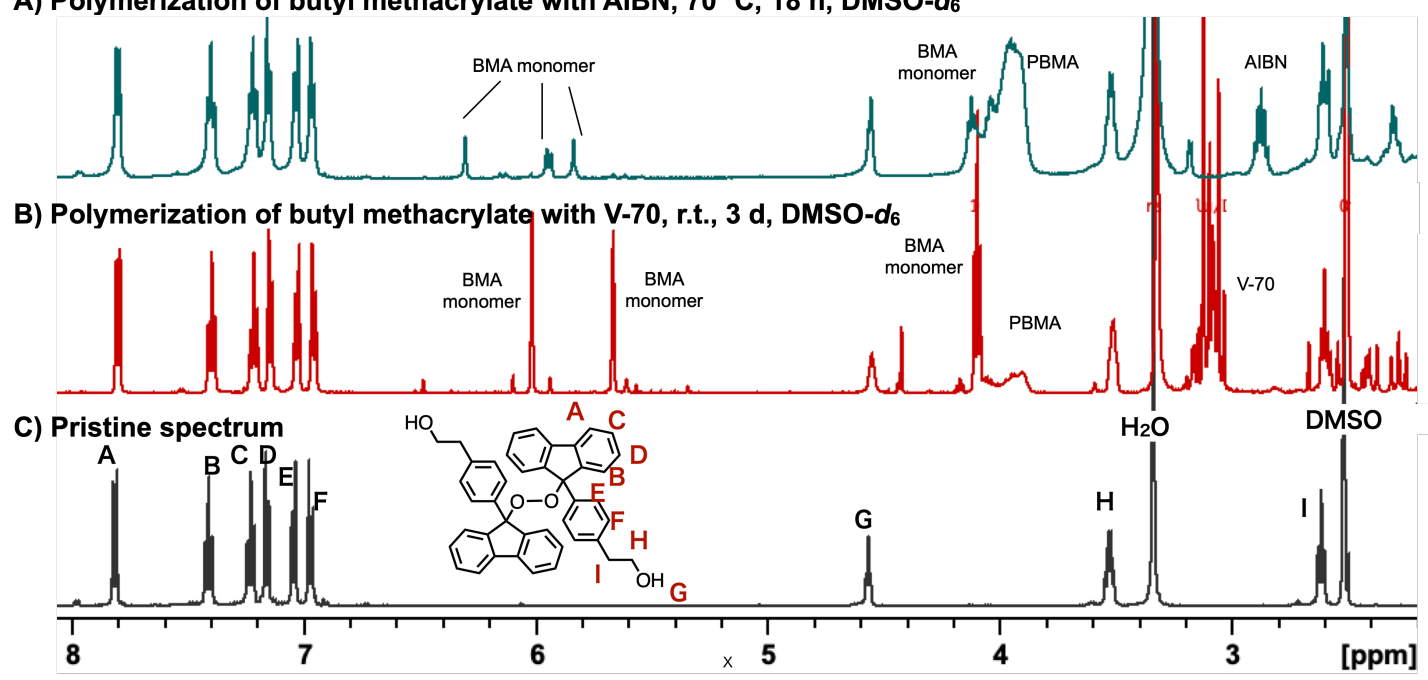

Figure S2. ${ }^{1} \mathrm{H}$ NMR spectra of (A), (B) BMPF-1-diol in polymerization systems; and (C) BMPF-1-diol only. $\left(500 \mathrm{MHz}, \mathrm{DMSO}-d_{6}, 25^{\circ} \mathrm{C}\right)$ 


\section{Grinding tests}

4.1 General information

Grinding tests were performed on a Retsch Mixer Mill MM 400 at room temperature. The applied energy was controlled by vibrational frequency and grinding time.

4.2 Grinding test to BMPF-1-diol

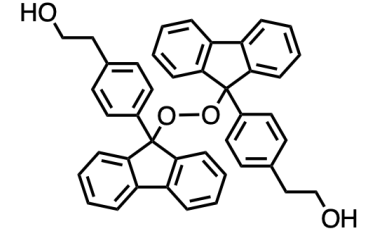

BMPF-1-diol

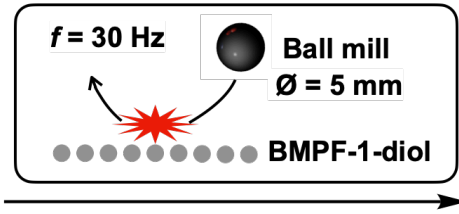

Mechanochemical reaction

r.t., $3 \mathrm{~h}$

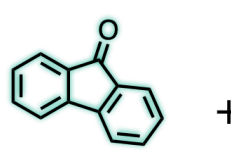

$1 \%$

9-fluorenone

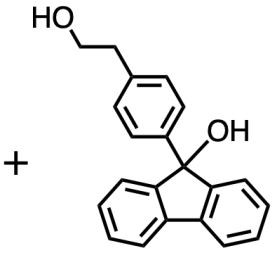

trace amount

9-aryl-9-fluorenol

Figure S3. Mechanochemical reaction of BMPF-1-diol.

\subsubsection{Mechanochemical reaction}

$600 \mathrm{mg}(1.0 \mathrm{mmol})$ of BMPF-1-diol was weighed and charged into the grinding jar of the ball-mill device together with a stainless-steel ball having a diameter of $5 \mathrm{~mm}$. The vibrational frequency was set as $30 \mathrm{~Hz}$. The grinding time was set as 30 minutes for 6 times with intervals of 10 minutes to avoid overheating caused by friction. After the grinding, the solid inside the jar was dissolved in dichloromethane and subjected to column chromatography (silica gel, EtOAc hexane $=1 / 20$ to $4 / 1, \mathrm{v} / \mathrm{v}$ ) to afford a yellow solid 9-fluorenone (3.5 mg, $0.019 \mathrm{mmol}, 0.97 \%$ ) and 9-aryl-9-fluorenol (0.8 $\mathrm{mg}, 0.0027 \mathrm{mmol}, 0.14 \%)$ as the major product. The recovery rate of BMPF-1-diol was 95\% (570 mg recovered).

The NMR spectrum of 9-fluorenone was identical with that of 9-fluorenone from commercial source (Tokyo Chemical Industry).

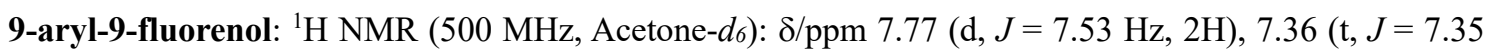
$\mathrm{Hz}, 2 \mathrm{H}), 7.21-7.33$ (m, 6H), 7.12 (d, $J=8.07 \mathrm{~Hz}, 2 \mathrm{H}), 5.08$ (s, 1H), 3.70 (q, $J=6.50 \mathrm{~Hz}, 2 \mathrm{H}), 3.60$ (t, $J=$ $5.38 \mathrm{~Hz}, 1 \mathrm{H}), 2.75(\mathrm{t}, J=7.03 \mathrm{~Hz}, 2 \mathrm{H})$.

FAB-MS (m/z): [M+ $]$ calcd. for $\mathrm{C}_{21} \mathrm{H}_{18} \mathrm{O}_{2}: 302.3657$; Found, 302.3660 . 


\subsubsection{EPR measurements to the ground sample}

EPR measurements were carried out on a JEOL JES-X320 X-band EPR spectrometer. The spectra of ground BMPF-1-diol were measured using a microwave power of $0.1 \mathrm{~mW}$, field modulation of $0.11 \mathrm{mT}$ with a time constant of $0.03 \mathrm{~s}$, a sweep rate of $0.125 \mathrm{mT} / \mathrm{s}$ at $25^{\circ} \mathrm{C}$. The $\mathrm{Mn}^{2+}$ signal was used as an auxiliary standard. The $g$ value was calculated according to the following equation: $g=h n / \beta H$ where $h$ is the Planck constant, $n$ is the microwave frequency, $\beta$ is the Bohr magneton, and $H$ is the magnetic field.

A)

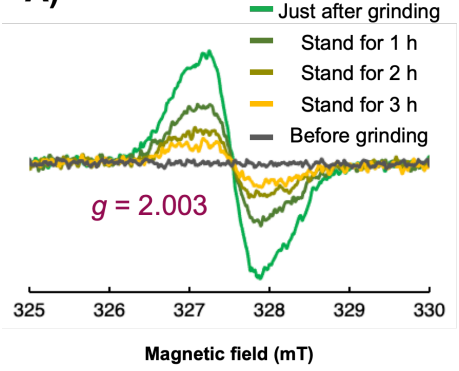

B)

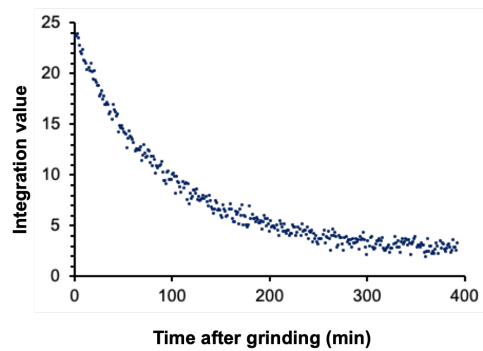

C)

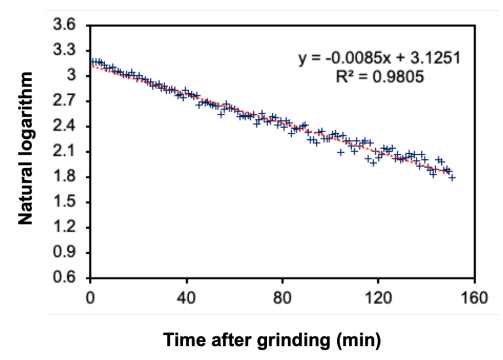

Figure S4 (A) Signal profile in EPR measurements, (B) integration value versus holding time, (C) natural logarithms of the integration values versus holding time.

$18 \mathrm{mg}$ of the ground BMPF-1-diol was weighed, charged into a quartz sample tube, and subjected to EPR measurement. The profiles of radical signals in EPR measurement were shown in Figure S4 (A). The measurements were taken for every 1.1 minutes. The integration values were plotted against the time after grinding in Figure S4 (B). The natural logarithms of integration values were plotted against the time after grinding in Figure S4 (C) to calculate $k=-0.0085$. The half-life time 81.5 minutes was calculated using the equation:

$$
t_{\frac{1}{2}}=\frac{\ln 2}{k}=81.5
$$




\subsubsection{Fluorescence spectrum of BMPF-1-diol after grinding}

\subsubsection{Solid-state fluorescence spectra}

$10 \mathrm{mg}$ of BMPF-1-diol before and after grinding were weighed and charged into the quartz cell and the fluorescence measurements were conducted respectively $\left(\lambda_{\mathrm{ex}}=365 \mathrm{~nm}\right)$. The spectra were shown in Figure S5.

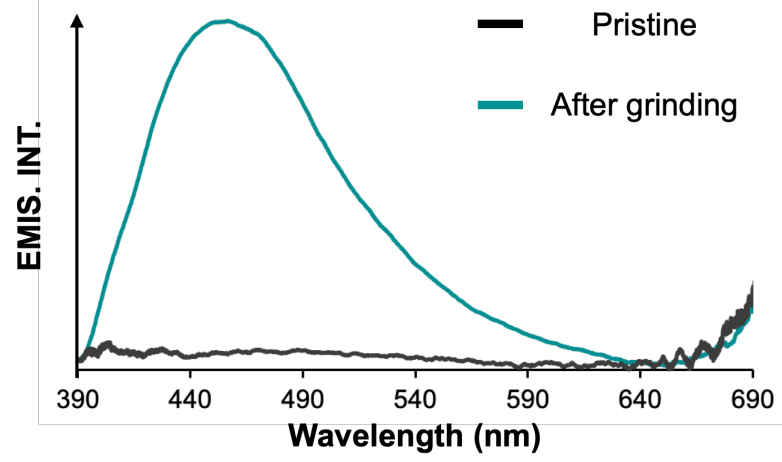

Figure S5. Solid-state fluorescence spectra of BMPF-1-diol before and after grinding.

\subsubsection{Solution fluorescence spectra in ethanol}

$40 \mathrm{mg}$ of ground sample was weighed and dissolved in $3 \mathrm{~mL}$ of ethanol. $1 \mathrm{mg}$ of 9-fluorenone from commercial source was dissolved in $10 \mathrm{~mL}$ of ethanol. The two solutions were transferred to quartz cells and subjected to UV-Vis absorption and fluorescence measurements ( $\lambda_{\mathrm{ex}}=365 \mathrm{~nm}$ ). The absorption and fluorescence intensities were normalized using max normalization. The results were compared in Figure S6.

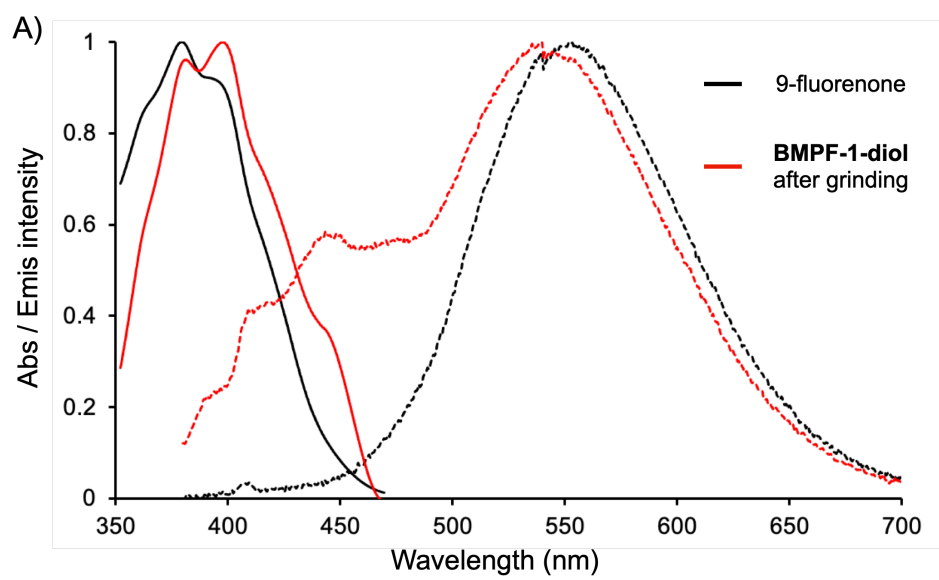

B)

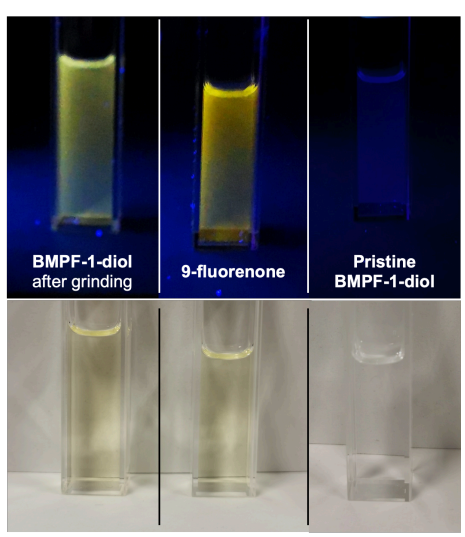

Figure S6. (A) Solution UV-Vis absorption spectra (solid line) and fluorescence spectra (dashed line) of the ground sample and 9-fluorenone from commercial source; (B) photographs under visible (lower) and UV light (upper, $\lambda_{\mathrm{ex}}=365 \mathrm{~nm}$ ). 
4.3 Grinding tests to the polymer networks BMPF-1-PB, BMPF-2-PB and BPA-PB

\subsubsection{General information}

About $200 \mathrm{mg}$ of polymer samples were charged into the grinding jar, together with a stainless-steel ball having a diameter of $5 \mathrm{~mm}$. The vibration frequency was set as $30 \mathrm{~Hz}$ and the grinding time was set as mentioned.

\subsubsection{Solid-state fluorescence spectra of ground samples}

About $15 \mathrm{mg}$ of ground sample was weighed and charged into the quartz cell for fluorescence analysis. The excitation wavelength was set as $365 \mathrm{~nm}$. The normalized intensity of fluorescence was derived from $\mathrm{I}_{\mathrm{NORM}}=\mathrm{IS}_{\mathrm{S}} / \mathrm{m}_{\mathrm{S}}$, where $\mathrm{I}_{\mathrm{S}}$ is the peak height and $\mathrm{m}_{\mathrm{S}}$ was the actual weight of the ground sample in the quartz cell.

\subsubsection{Fluorescence spectra of the solution extracted from the ground samples}

To $130 \mathrm{mg}$ of ground samples of BMPF-1-PB and BMPF-2-PB after 60-min grinding were added $5 \mathrm{~mL}$ of acetonitrile, respectively. The mixtures were well mixed and passed through membrane filters to remove the insoluble network residues. The resulting solutions were transferred into quartz cells and subjected to fluorescence measurements. The emission intensities of BMPF-1-PB and BMPF-2-PB after grinding were normalized to the maximum intensities in BMPF-1-PB. The spectra were compared with that of 9fluorenone at low concentration in acetonitrile in Figure S7.
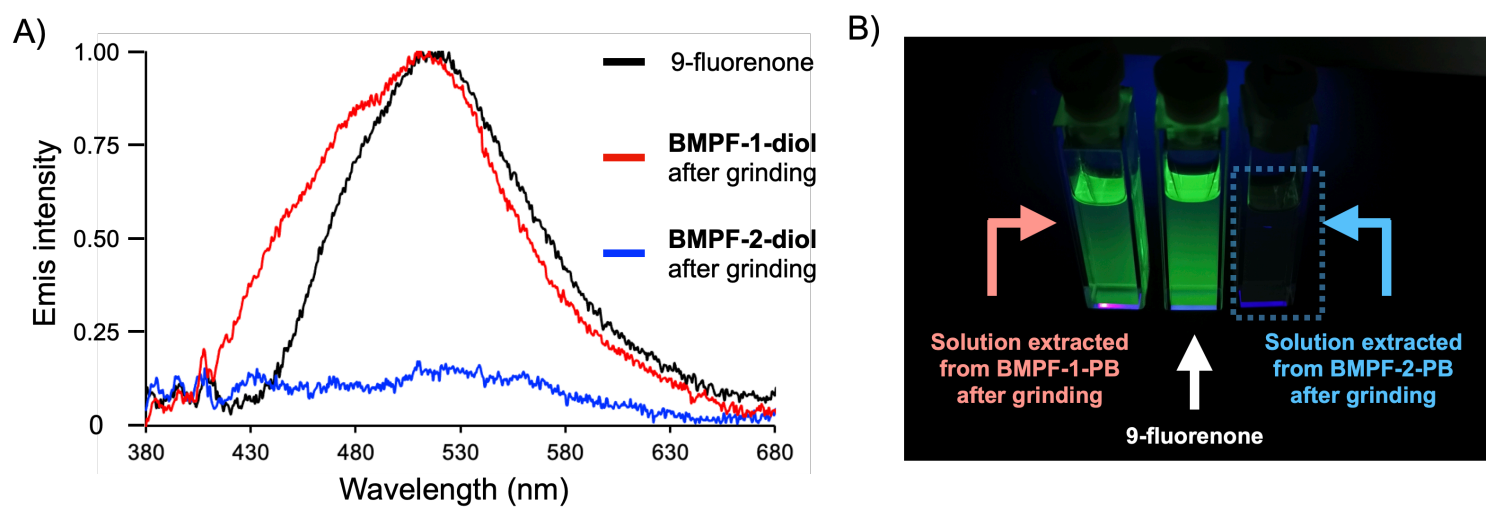

Figure S7. (A) Fluorescence spectra of the acetonitrile solution extracted from the ground samples of BMPF-1-PB and BMPF-2-PB after 60-min grinding, and 9-fluorenone diluted solution; (B) photographs under $365 \mathrm{~nm}$ UV irradiation. 


\subsubsection{Preparations for quantitative HPLC analysis}

The solutions extracted from the ground samples of BMPF-1-PB and BMPF-2-PB in section 4.3.3 were subjected to HPLC analysis. The intensities in both measurements were normalized to the maximum intensities in BMPF-1-PB. Their HPLC profiles (elution solvent: $\mathrm{CH}_{3} \mathrm{CN} / \mathrm{H}_{2} \mathrm{O}=80 / 20$, v/v; detected using UV absorbance at $254 \mathrm{~nm}$ ) were compared with the ones of 9-fluorenone, biphenyl, and 4,4'dimethylbiphenyl in Figure S8.

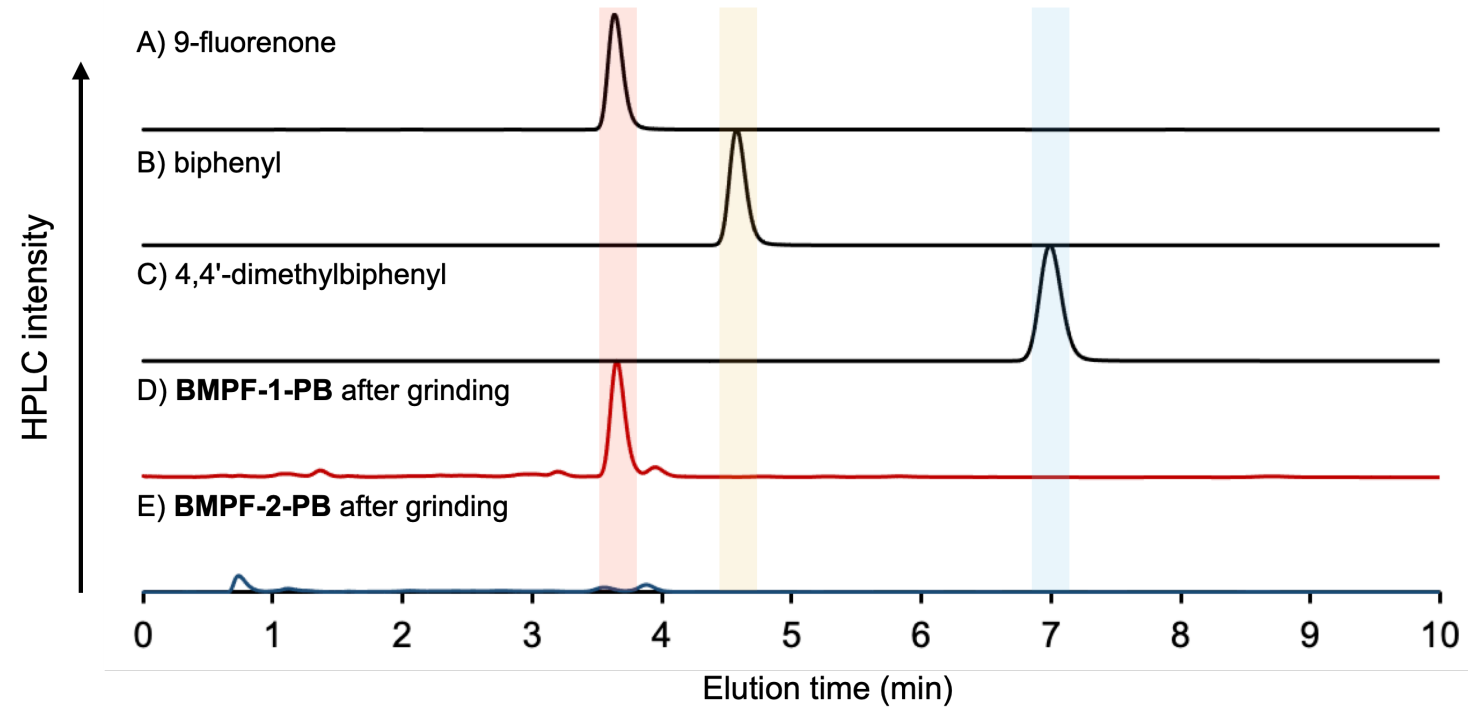

Figure S8. HPLC profiles of (A) 9-fluorenone, (B) biphenyl, (C) 4,4'-dimethylbiphenyl, (D) BMPF-1-PB after 60-min grinding, (E) BMPF-2-PB after 60-min grinding.

\subsubsection{Quantitative HPLC analysis}

A)

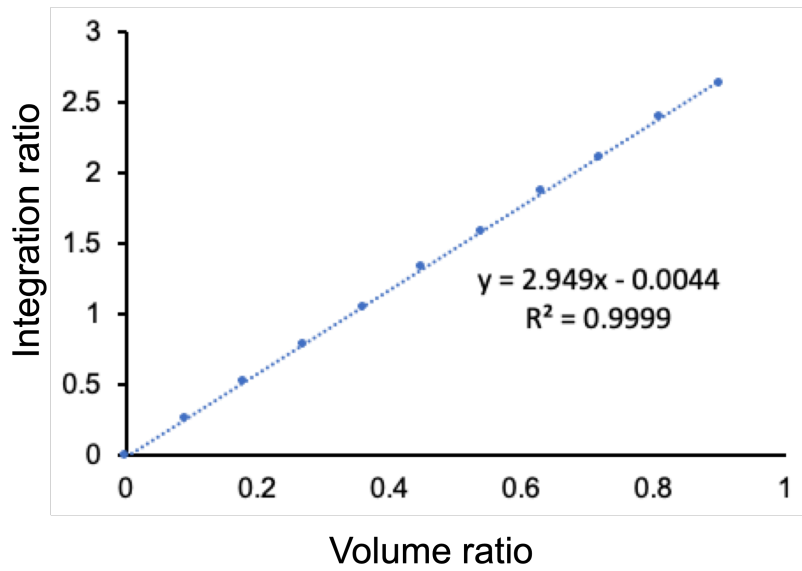

B)

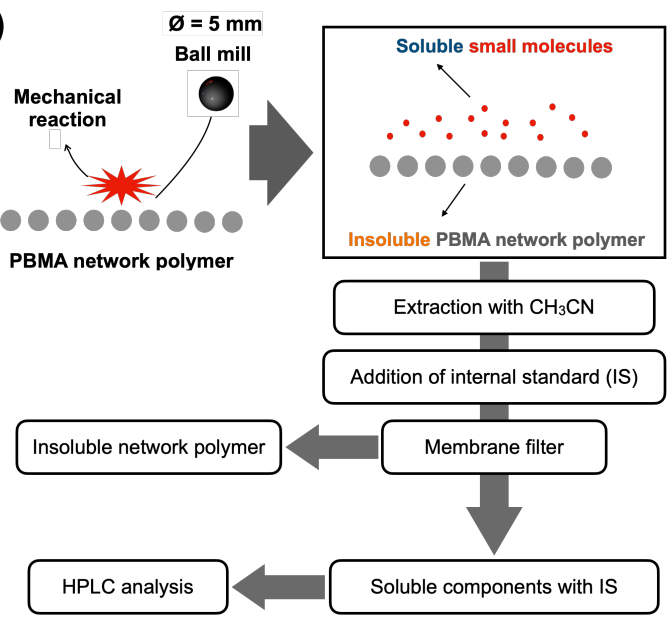

Figure S9 (A) Plot of integration ratios of 9-fluorenone and biphenyl in HPLC against volume ratios, (B) Illustration of the method to determine the amount of 9-fluorenone released from BMPF-1-PB. 


\subsubsection{Establishment of the linear regression equation}

$22.8 \mathrm{mg}$ of 9-fluorenonone was dissolved with $\mathrm{CH}_{3} \mathrm{CN}$ in a $50 \mathrm{~mL}$ volumetric flask as the standard solution A. $22.0 \mathrm{mg}$ of biphenyl was dissolved with $\mathrm{CH}_{3} \mathrm{CN}$ in a $50 \mathrm{~mL}$ volumetric flask as the standard solution B. 90/180/270/360/450/540/630/720/810/900 $\mu \mathrm{L}$ solution A was mixed with $1 \mathrm{~mL}$ solution B and the mixed solution was subjected to HPLC analysis. As shown in Figure S9 (A), the y axis was the integration ratio between the peak of 9-fluorenone and the peak of biphenyl, the $\mathrm{x}$ axis was the dosage volume ratio between them.

\subsubsection{Calculation of the amount of 9-fluorenone released from BMPF-1-PB}

As illustrated in Figure S9 (B), the ground sample was mixed with $10 \mathrm{~mL}$ of $\mathrm{CH}_{3} \mathrm{CN}$ and to the mixture was added $300 \mu \mathrm{L}$ standard solution B as the internal standard. The resulting mixture was filtered via a membrane filter to remove the insoluble network polymer. Obtained solution was subjected to HPLC analysis, from which the integration ratio $R$ between the peak of 9-fluorenone released from the network polymer and the peak of the internal standard can be derived. The weight of released 9-fluorenone, $m$, was calculated using the following equation:

$$
m=\frac{R}{2.949} \times 300 \times 0.00456
$$

In the equation, 2.949 was the slot of the linear regression curve. 300 was the amount of internal standard in $\mu \mathrm{L}, 0.00456$ was the concentration of standard solution $\mathrm{A}$ in $\mathrm{mg} / \mu \mathrm{L}$. 


\section{Compression tests}

Films were compressed using an IMC-1A45 press (Imoto Machinery Co., Ltd.). All processing was done at room temperature in air condition. The applied force was $5 \mathrm{kN}$. The area of compressed region was about $0.17 \mathrm{~cm}^{2}$. Thus, the applied stress was calculated as $300 \mathrm{MPa}$.

To $500 \mathrm{mg}$ of BPA-PH was added $21 \mathrm{mg}$ of BMPF-1-diol ( $0.035 \mathrm{mmol}, 1 \mathrm{~mol} \%)$ in $2 \mathrm{~mL}$ DMF. In the next, DMF was removed under reduced pressure. The mixture was dried in a vacuum oven at $50{ }^{\circ} \mathrm{C}$ overnight to give BMPF-m-BPA-PH as a transparent film. 


\section{Tensile tests}

Tensile tests were performed on SHIMADZU EZ-L instrument equipped with a $50 \mathrm{~N}$ load cell. BMPF1-PH was cut into a dumbbell shape and stretch at a speed of $20 \mathrm{~mm} / \mathrm{min}$. The stress-strain curve was given in Figure S10 (A). The photographs of BMPF-1-PH before and after stretching were given in Figure S10 (B). The photographs of BMPF-1-PH before and immediately after fracture were given in Figure S10 (C). Since no fluorescence phenomenon was observed, we conclude that the mechanochemical reaction did not occur by tensile elongation.
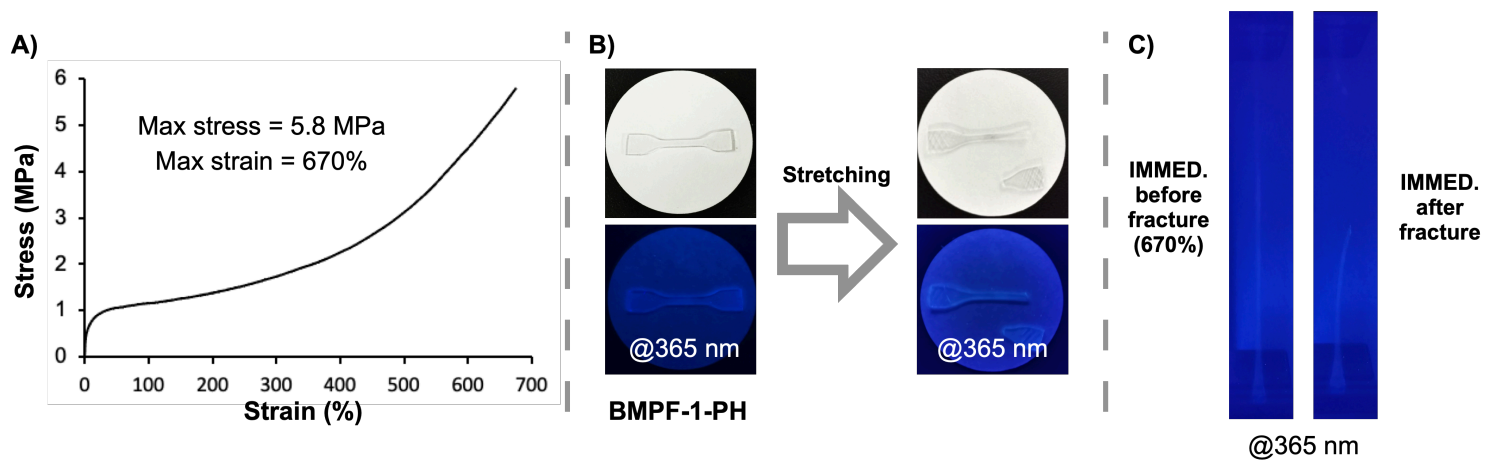

Figure S10. (A) Stress-strain curve of BMPF-1-PH, (B) photographs of BMPF-1-PH before and after stretching, (C) photographs of BMPF-1-PH before and after fracture. 


\section{DSC charts and $T_{\mathrm{g}}$ of polymer networks}

Differential scanning calorimetry (DSC) was carried out using a Shimadzu DSC-60A Plus differential scanning calorimeter at a heating rate of $5{ }^{\circ} \mathrm{C} / \mathrm{min}$ under $\mathrm{N}_{2}$ flow.
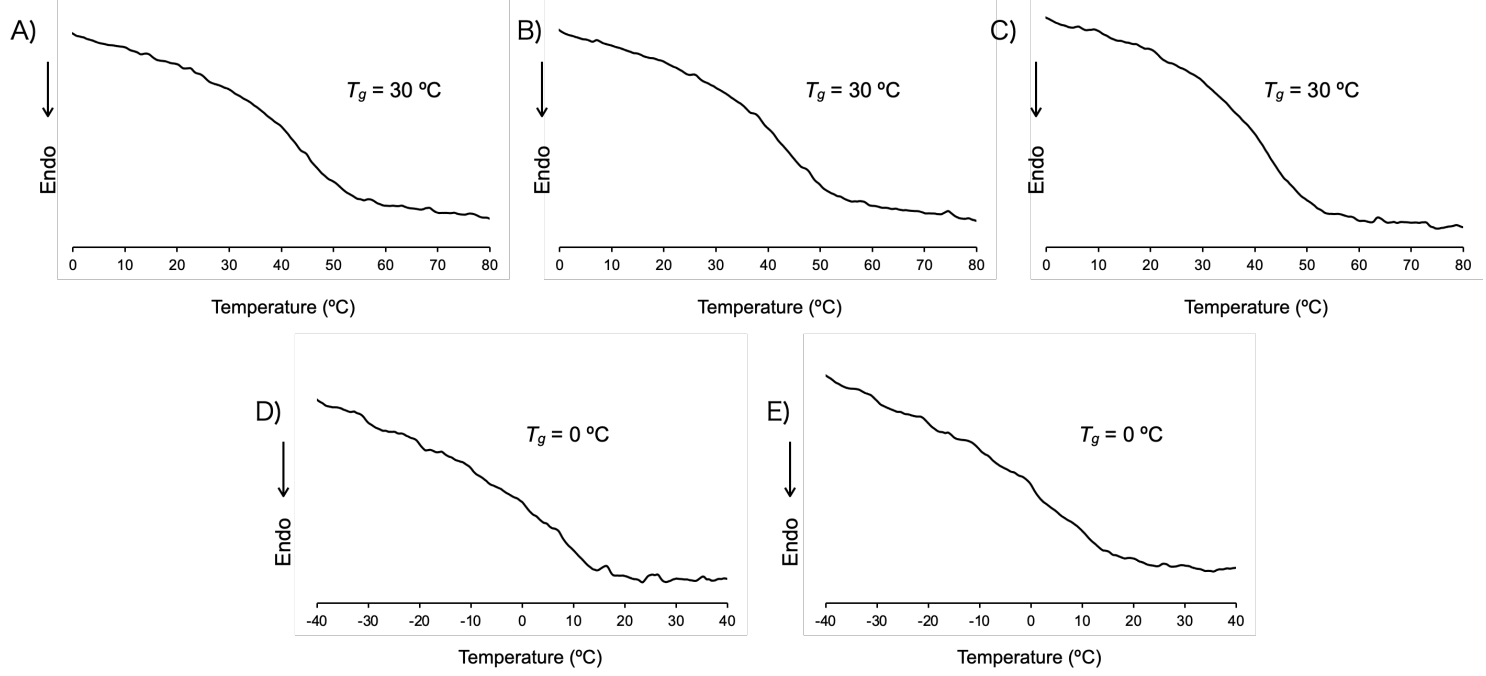

Figure S11. DSC charts and $T_{g}$ S of (A) BMPF-1-PB, (B) BMPF-2-PB, (C) BPA-PB, and (D) BMPF-1-PH, and (E) BPA-PB. 


\section{Thermogravimetric analysis}

Thermogravimetric analysis (TGA) measurements were performed on a SHIMADZU DTG-60 in a nitrogen stream of $50 \mathrm{~mL} / \mathrm{min}$ at a heating rate of $10{ }^{\circ} \mathrm{C} / \mathrm{min}$, ranging from $25^{\circ} \mathrm{C}$ to $600{ }^{\circ} \mathrm{C}$. The analysis revealed that BMPF-1-diol had a decomposition temperature at $5 \%$ weight loss of $200{ }^{\circ} \mathrm{C}$.

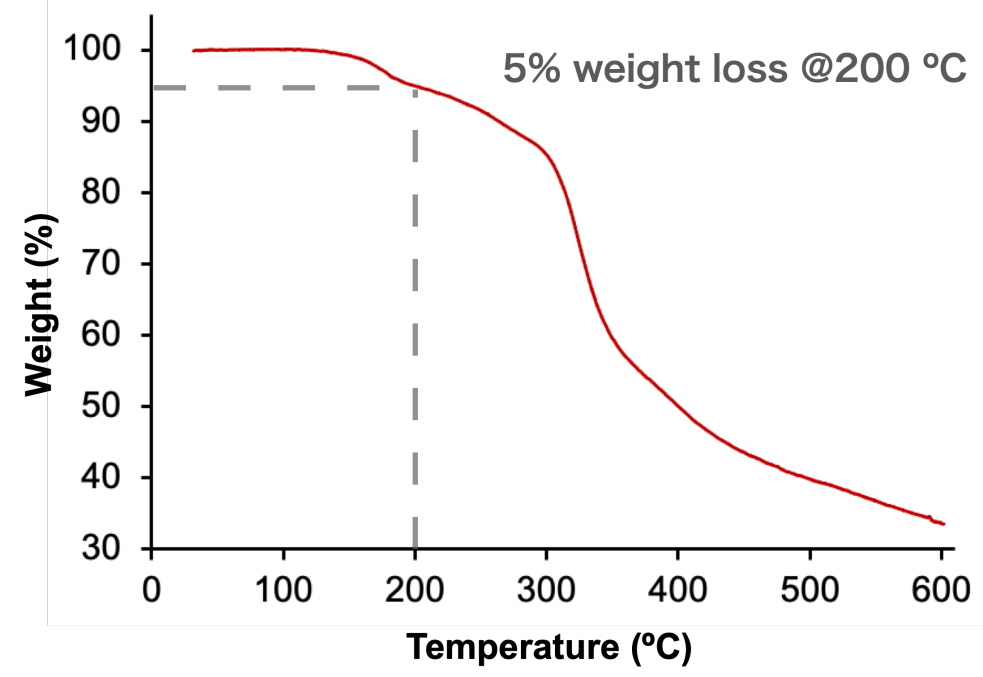

Figure S12. TGA analysis of BMPF-1-diol. 


\section{NMR spectra}

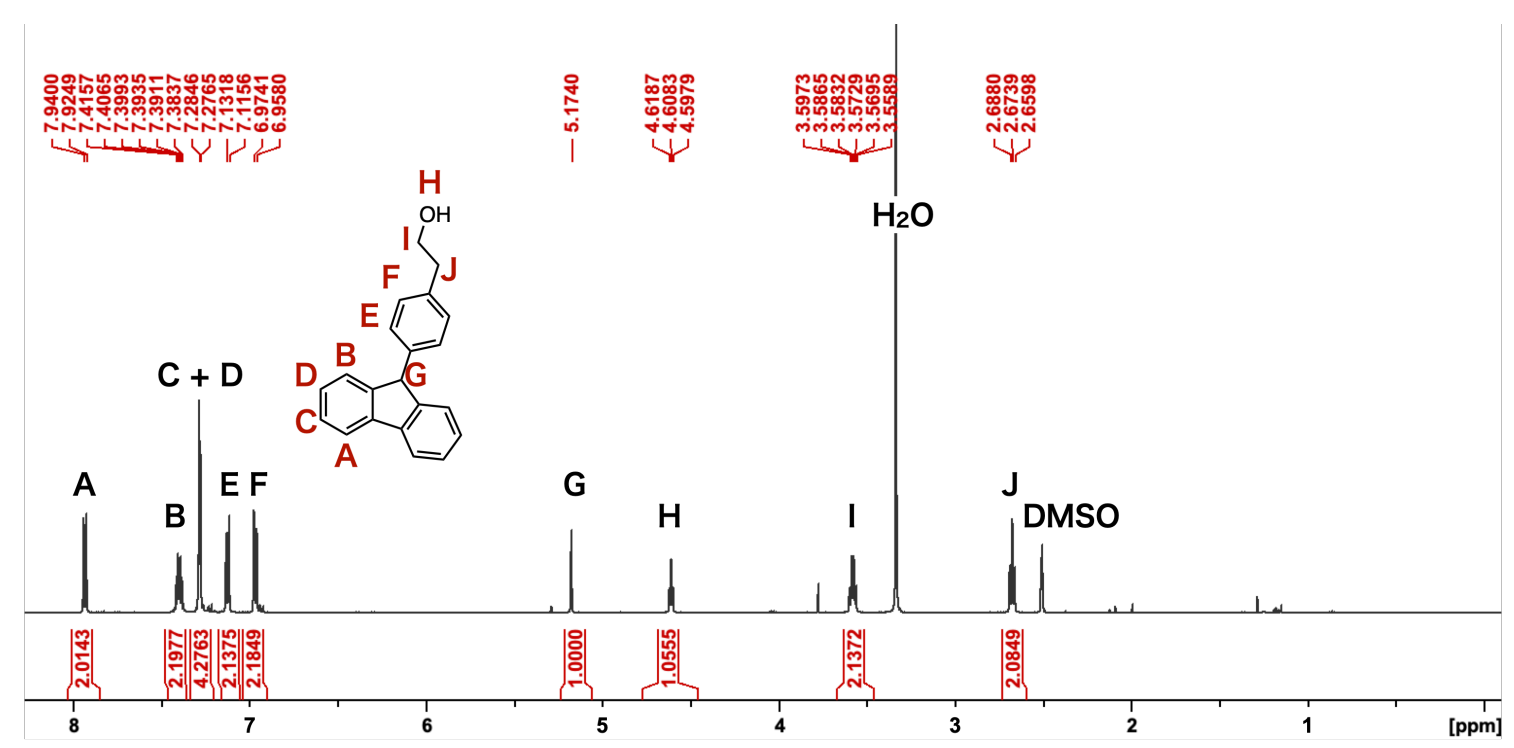

Figure S13. ${ }^{1} \mathrm{H}$ NMR spectrum of MPF-1-ol (500 MHz, DMSO- $\left.d 6,25{ }^{\circ} \mathrm{C}\right)$.

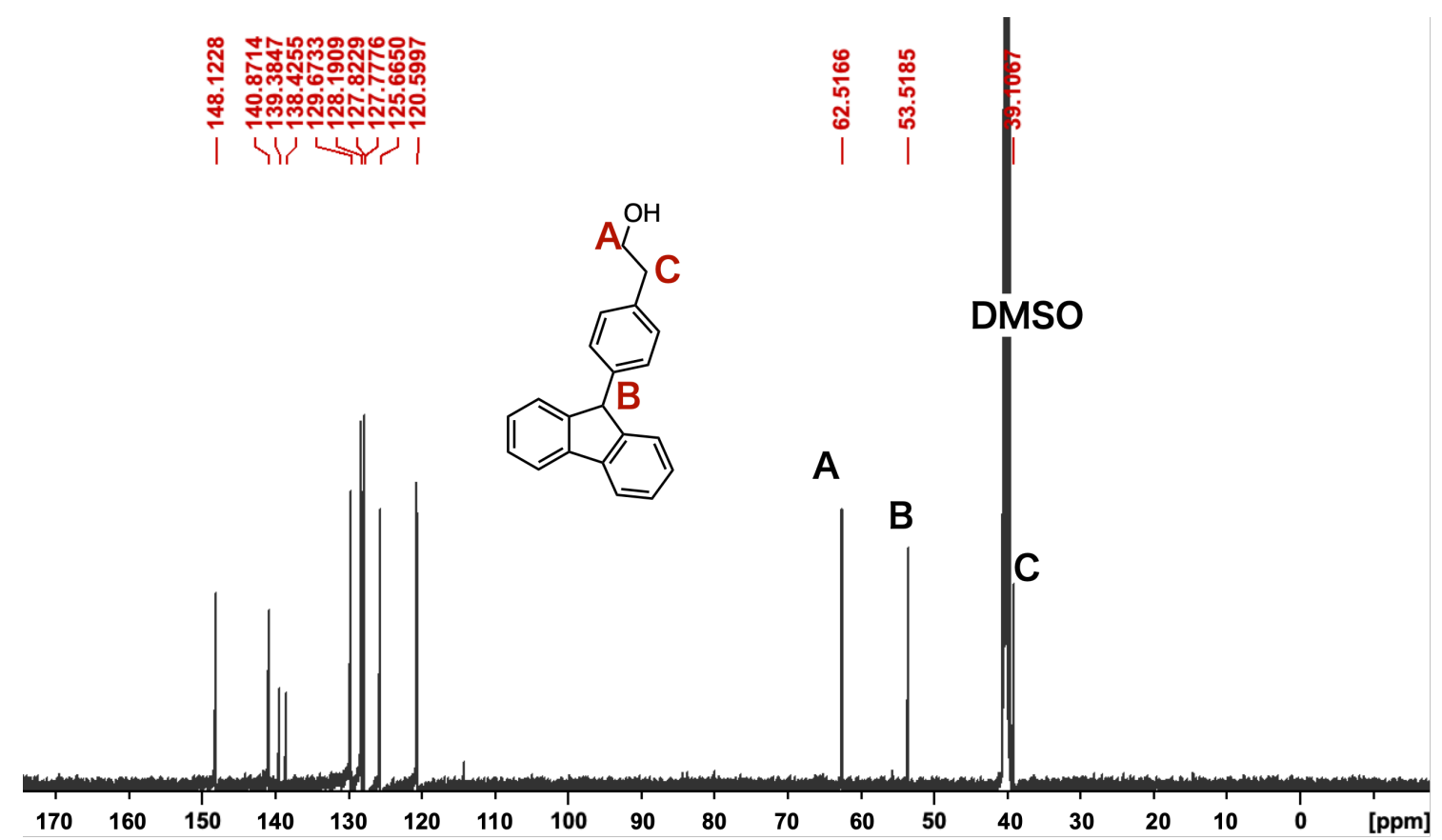

Figure S14. ${ }^{13} \mathrm{C}$ NMR spectrum of MPF-1-ol (125 MHz, DMSO- $d 6,25{ }^{\circ} \mathrm{C}$ ). 


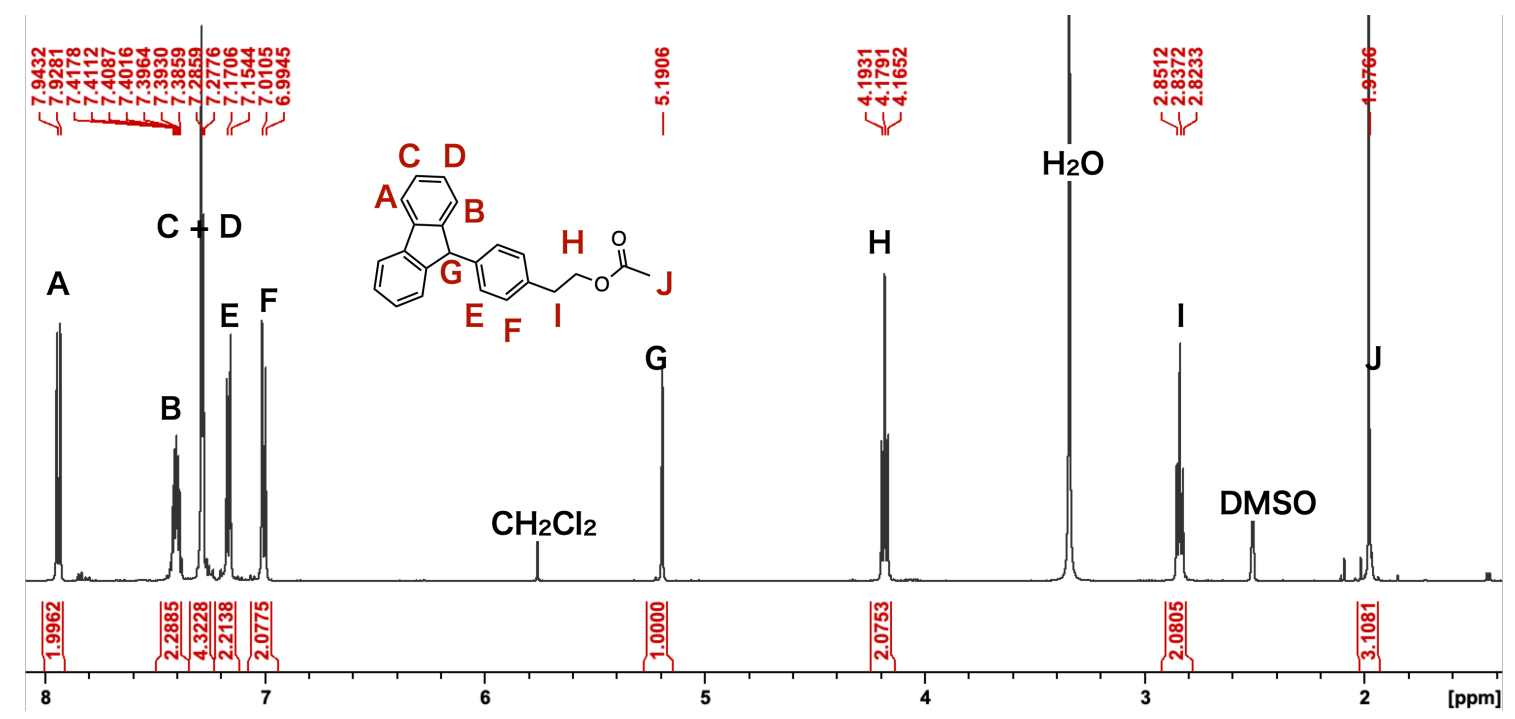

Figure S15. ${ }^{1} \mathrm{H}$ NMR spectrum of MPF-1-Pr (500 MHz, DMSO- $d_{\sigma}, 25{ }^{\circ} \mathrm{C}$ ).
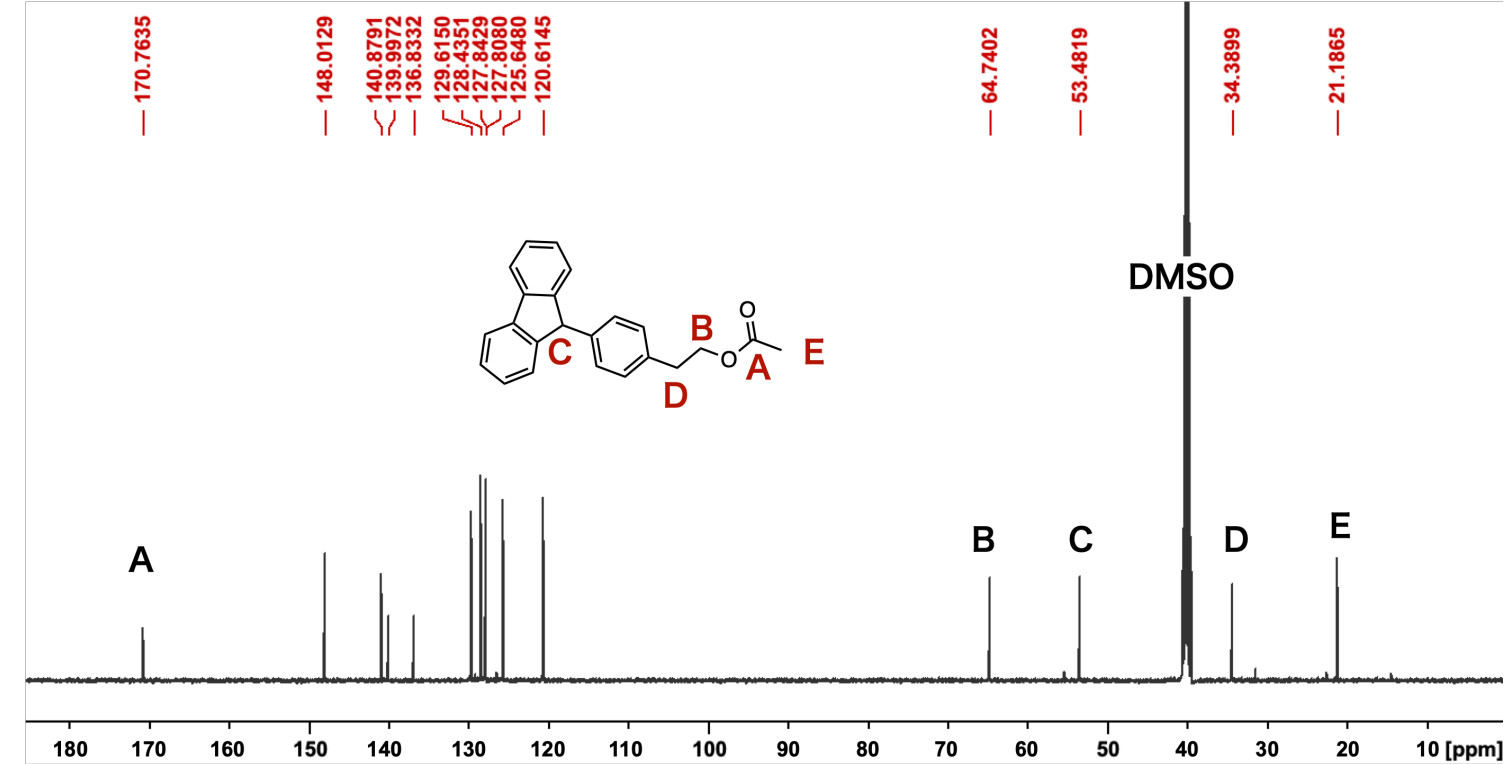

Figure S16. ${ }^{13} \mathrm{C}$ NMR spectrum of MPF-1-Pr $\left(125 \mathrm{MHz}, \mathrm{DMSO}-d_{6}, 25{ }^{\circ} \mathrm{C}\right)$. 


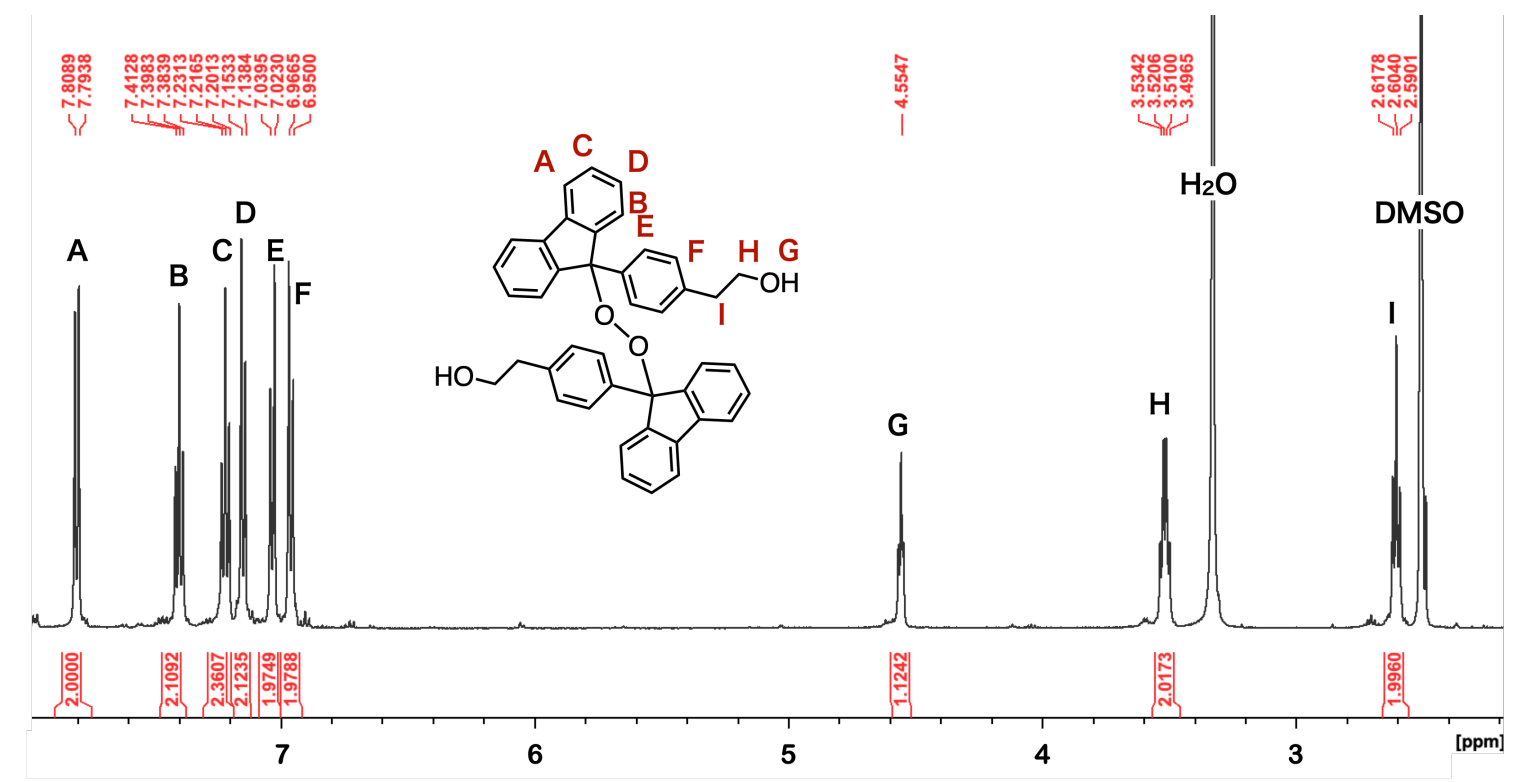

Figure S17. ${ }^{1} \mathrm{H}$ NMR spectrum of BMPF-1-diol (500 MHz, DMSO- $d_{6}, 25^{\circ} \mathrm{C}$ ).

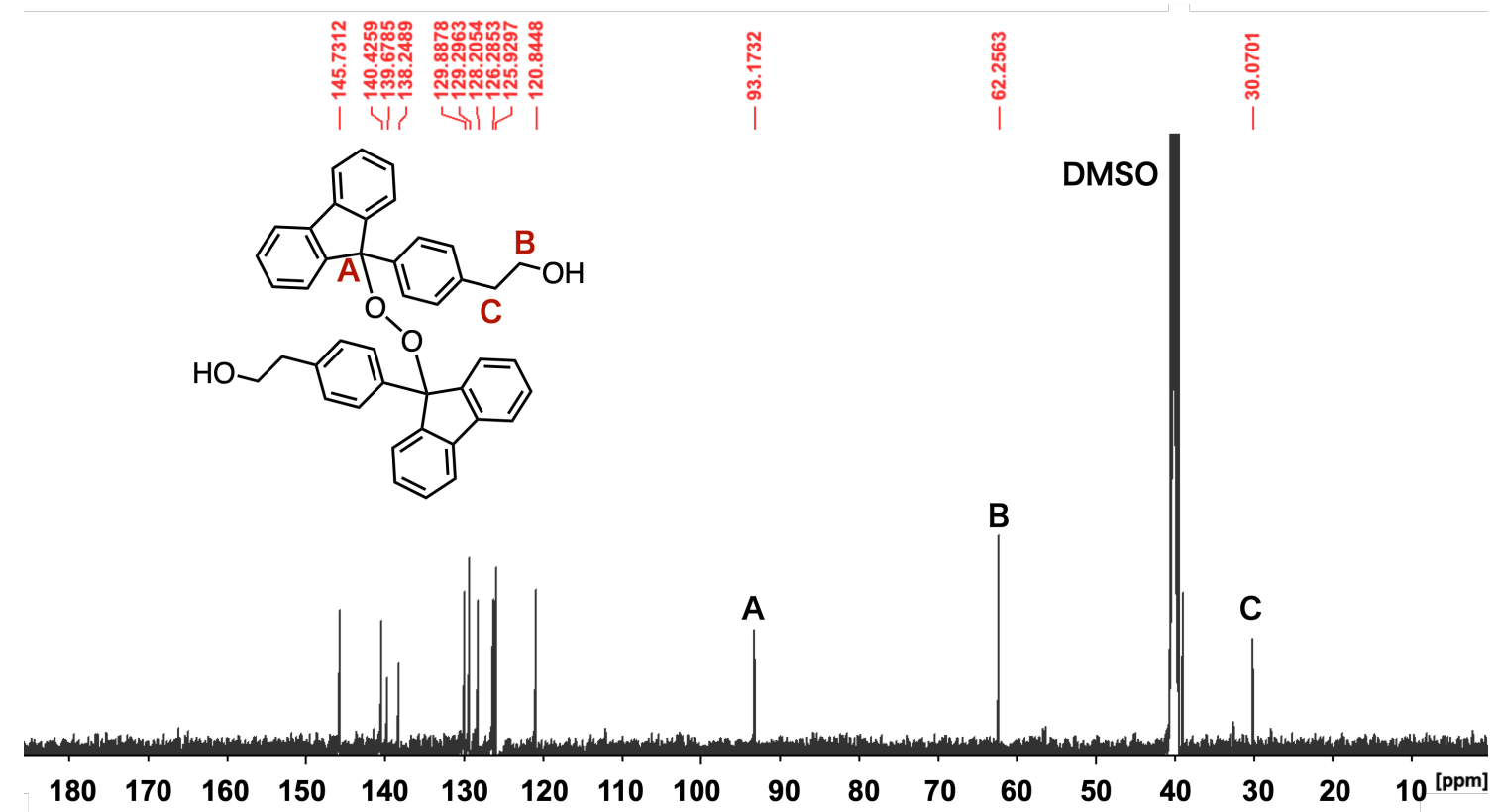

Figure S18. ${ }^{13} \mathrm{C}$ NMR spectrum of MPF-1-Pr $\left(125 \mathrm{MHz}\right.$, DMSO- $\left.d_{6}, 25^{\circ} \mathrm{C}\right)$. 


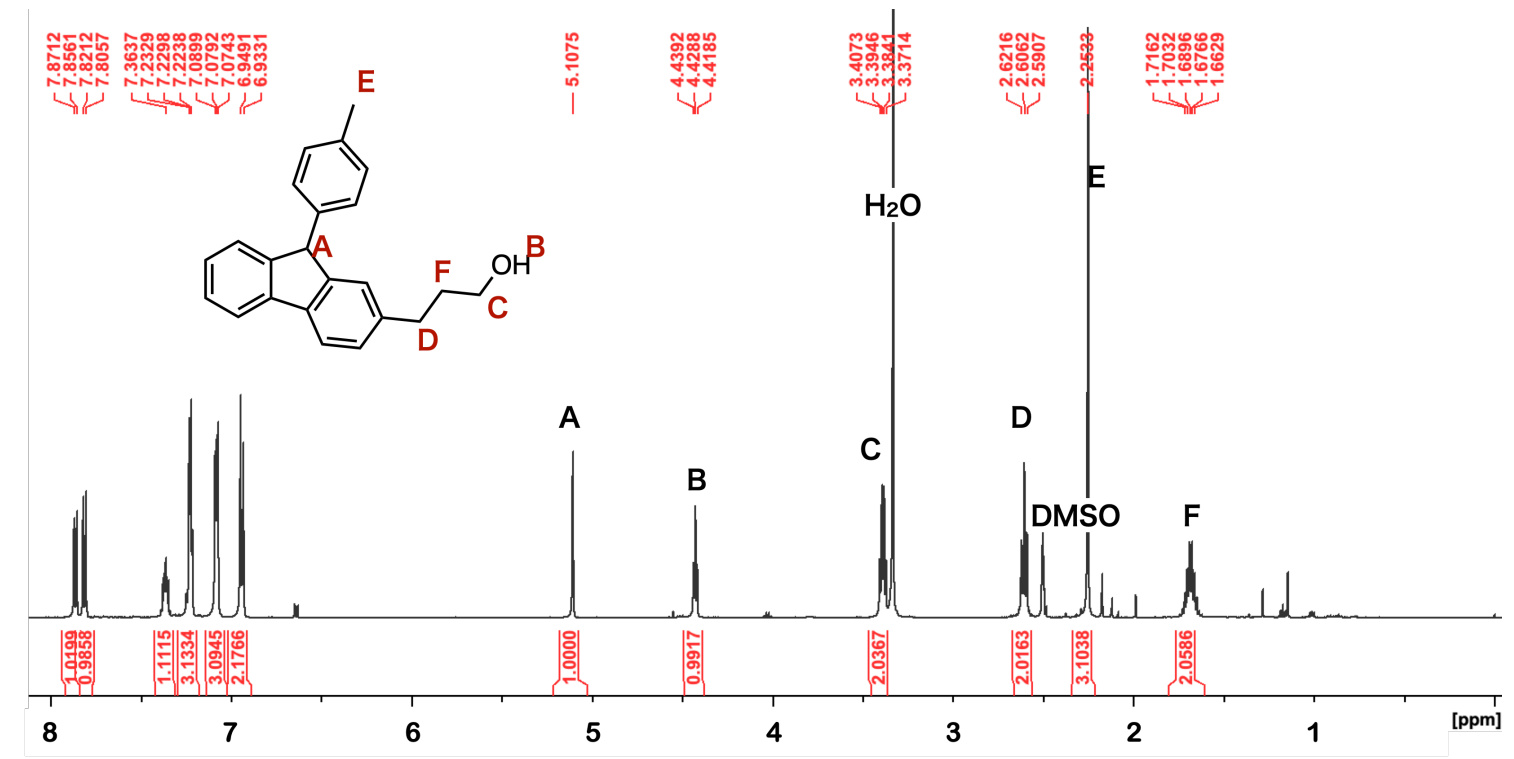

Figure S19. ${ }^{1} \mathrm{H}$ NMR spectrum of MPF-2-ol (500 MHz, DMSO- $d_{6}, 25^{\circ} \mathrm{C}$ ).

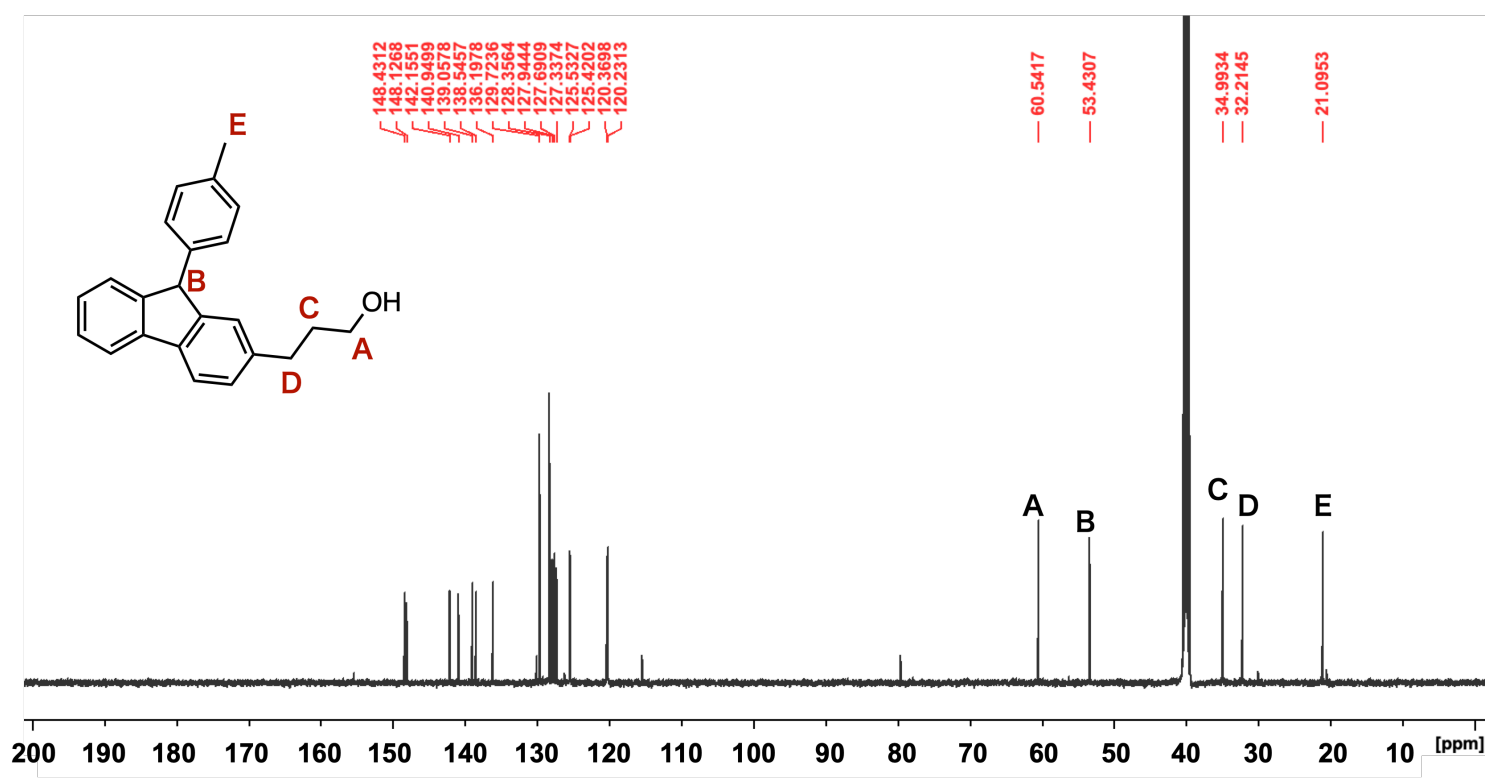

Figure S20. ${ }^{13} \mathrm{C}$ NMR spectrum of MPF-2-Pr $\left(125 \mathrm{MHz}\right.$, DMSO- $\left.d 6,25{ }^{\circ} \mathrm{C}\right)$. 


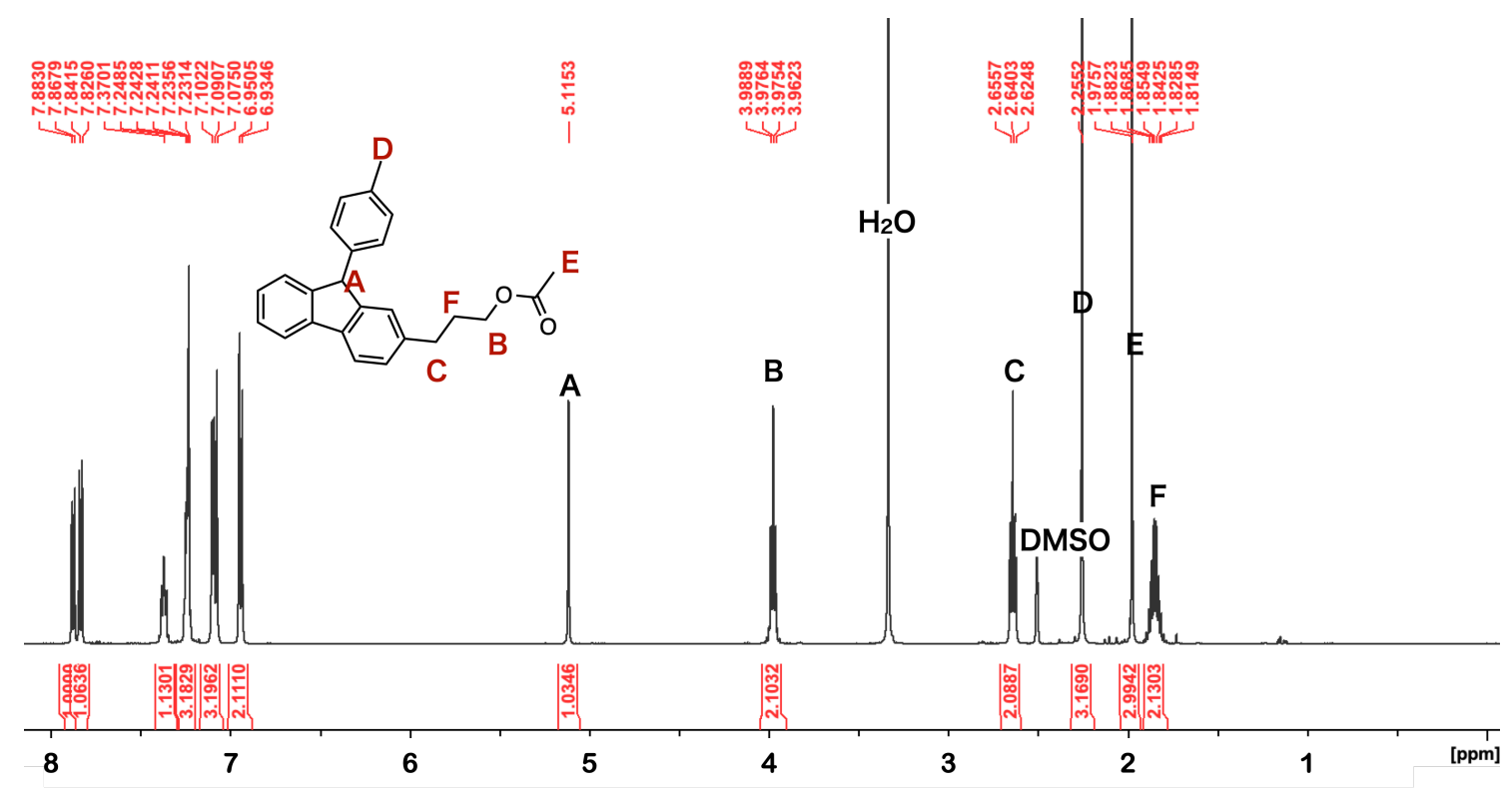

Figure S21. ${ }^{1} \mathrm{H}$ NMR spectrum of MPF-2-Pr $\left(500 \mathrm{MHz}\right.$, DMSO- $\left.d_{6}, 25^{\circ} \mathrm{C}\right)$.

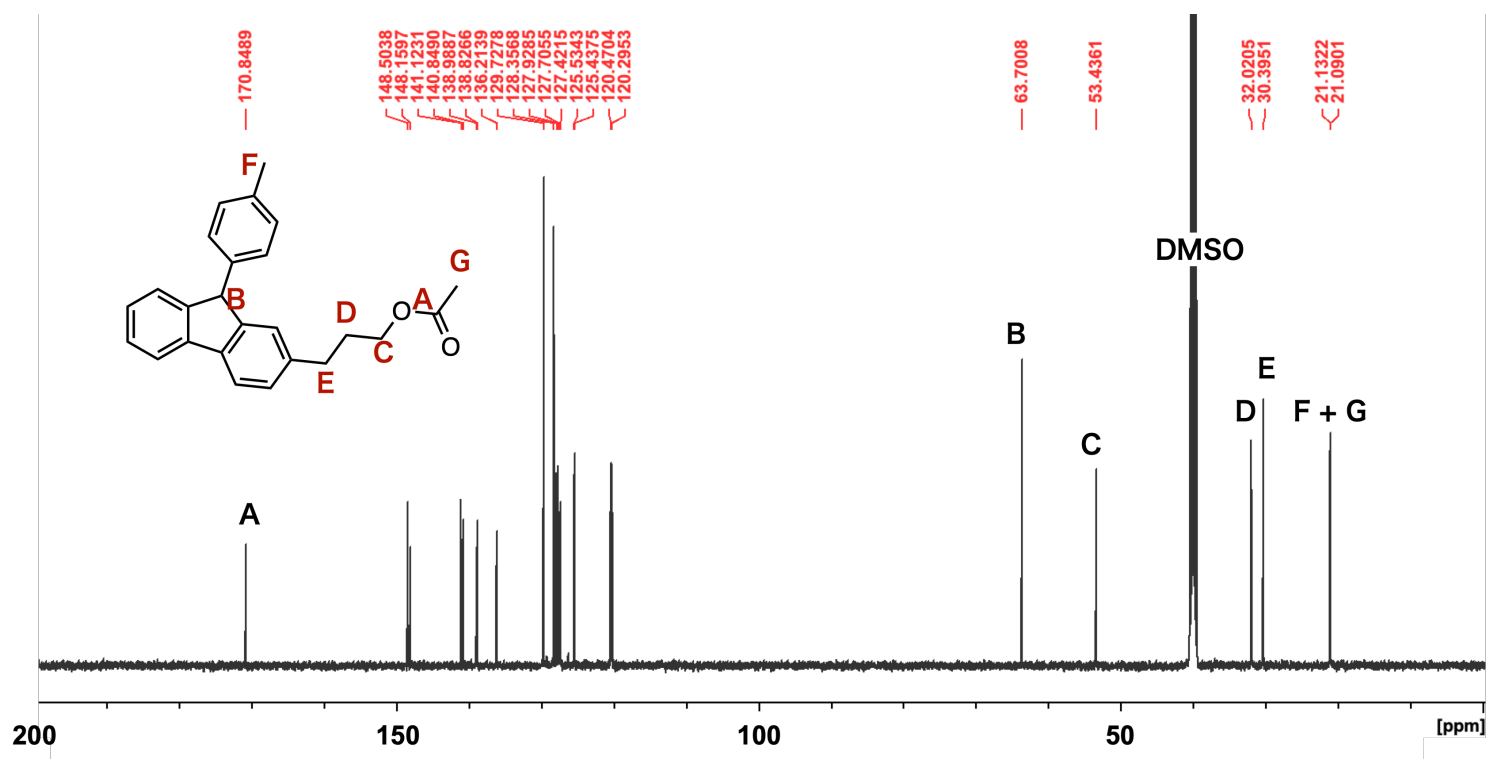

Figure S22. ${ }^{13} \mathrm{C}$ NMR spectrum of MPF-2-Pr $\left(125 \mathrm{MHz}\right.$, DMSO- $\left.d 6,25{ }^{\circ} \mathrm{C}\right)$. 


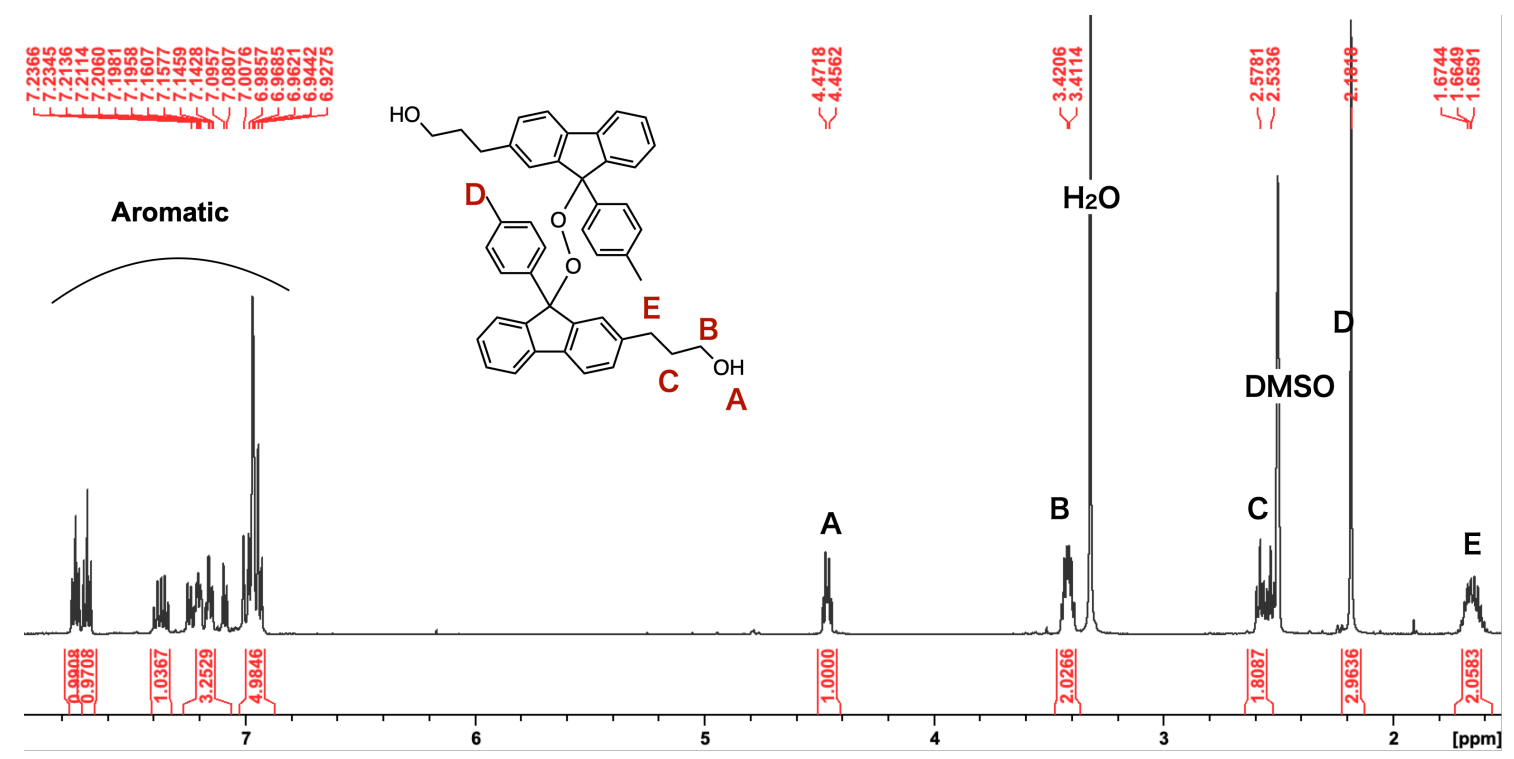

Figure S23. ${ }^{1} \mathrm{H}$ NMR spectrum of BMPF-2-diol (500 MHz, DMSO- $d 6,25^{\circ} \mathrm{C}$ ).

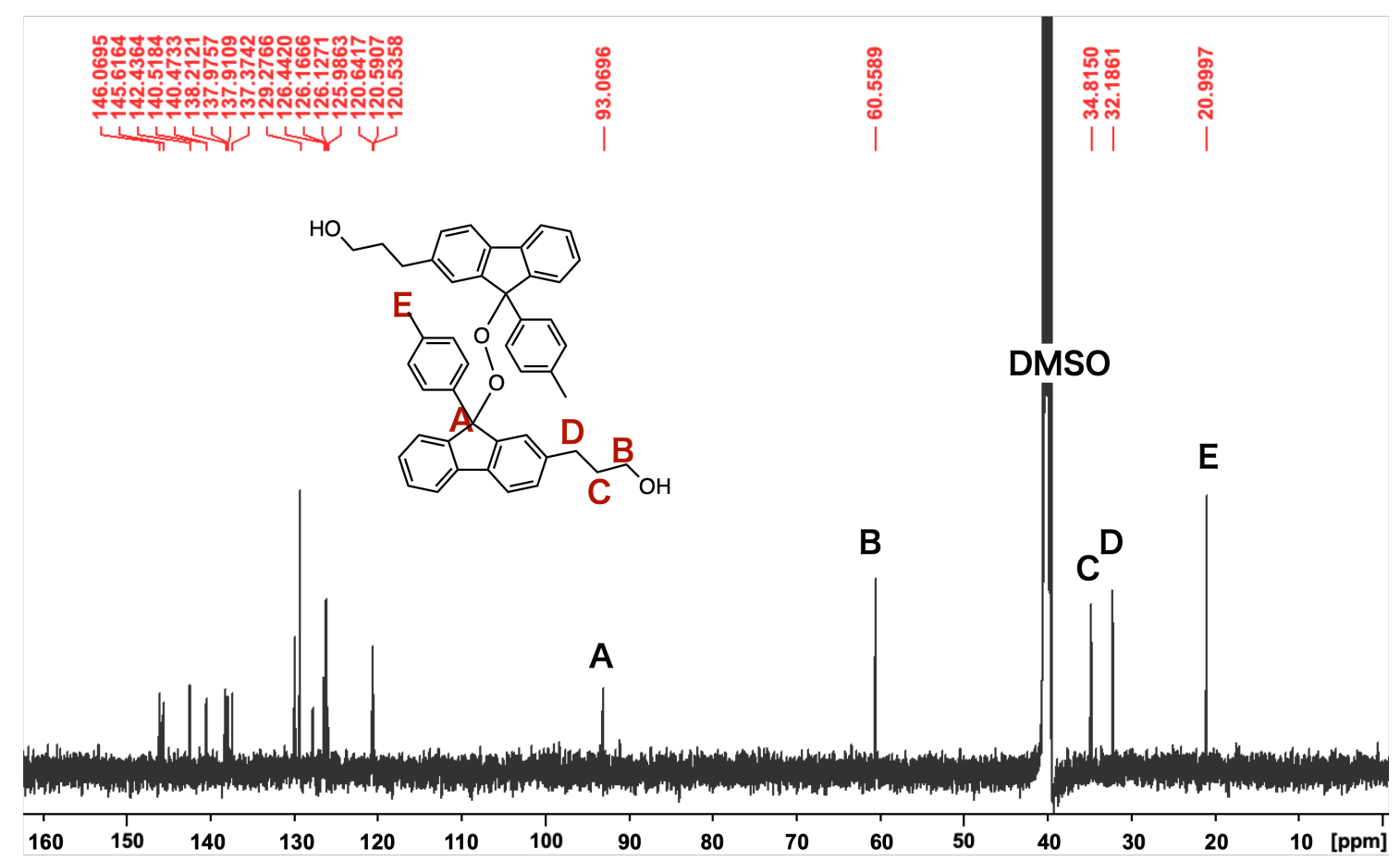

Figure S24. ${ }^{13} \mathrm{C}$ NMR spectrum of BMPF-2-diol $\left(125 \mathrm{MHz}\right.$, DMSO- $\left.d 6,25{ }^{\circ} \mathrm{C}\right)$. 


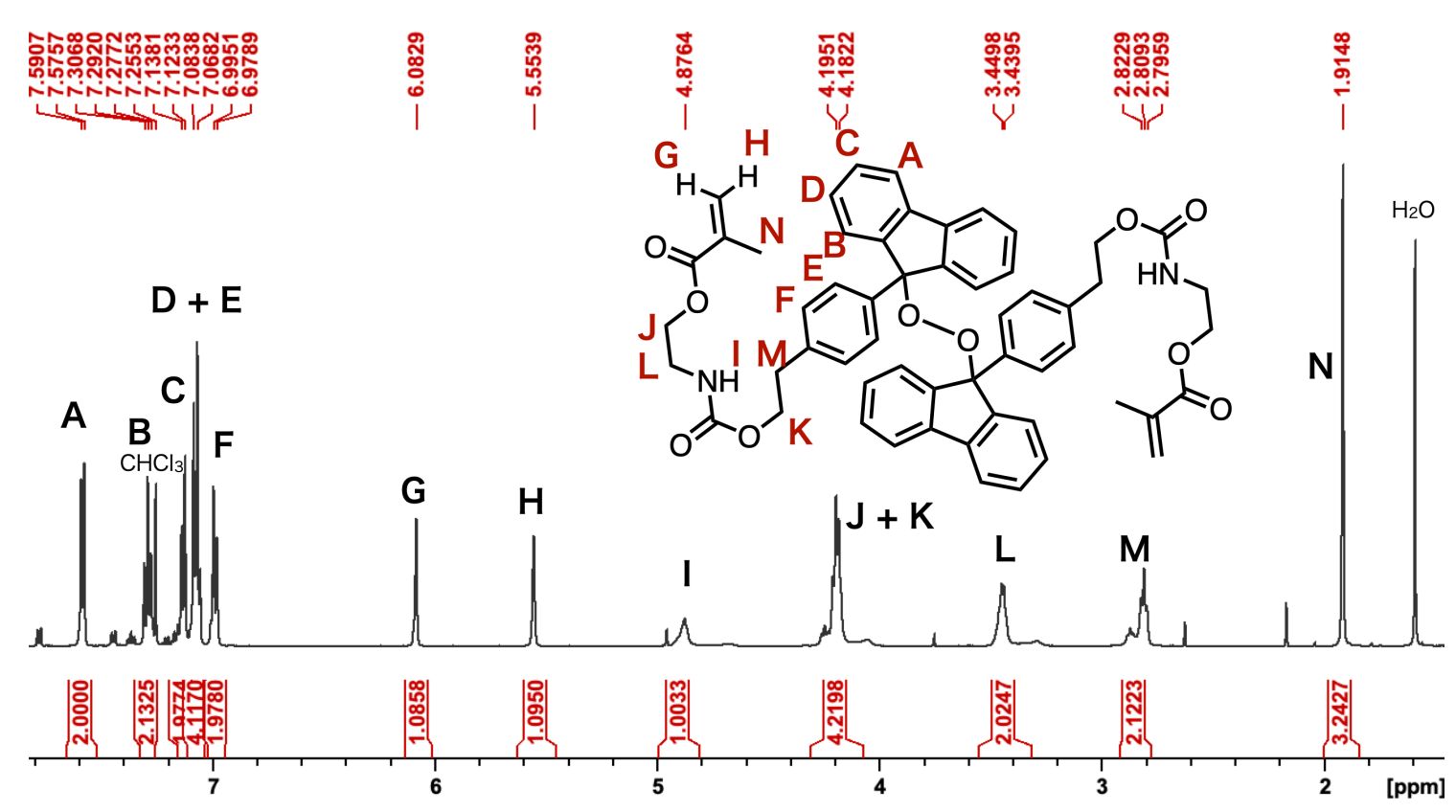

Figure S25. ${ }^{1} \mathrm{H}$ NMR spectrum of BMPF-1-VCL $\left(500 \mathrm{MHz}, \mathrm{CDCl}_{3}, 25^{\circ} \mathrm{C}\right)$.

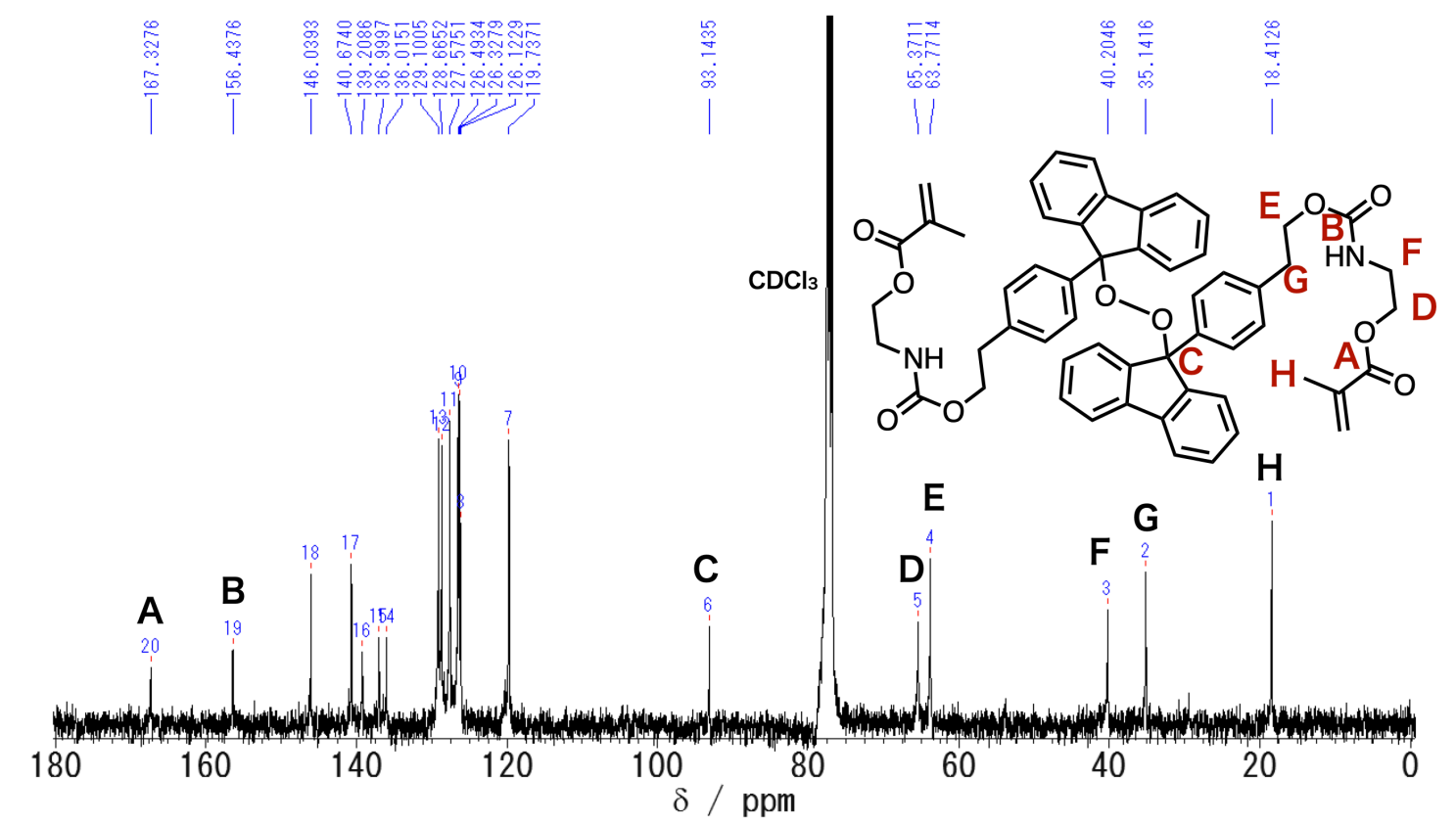

Figure S26. ${ }^{13} \mathrm{C}$ NMR spectrum of BMPF-1-VCL $\left(100 \mathrm{MHz}, \mathrm{CDCl}_{3}, 25^{\circ} \mathrm{C}\right)$. 


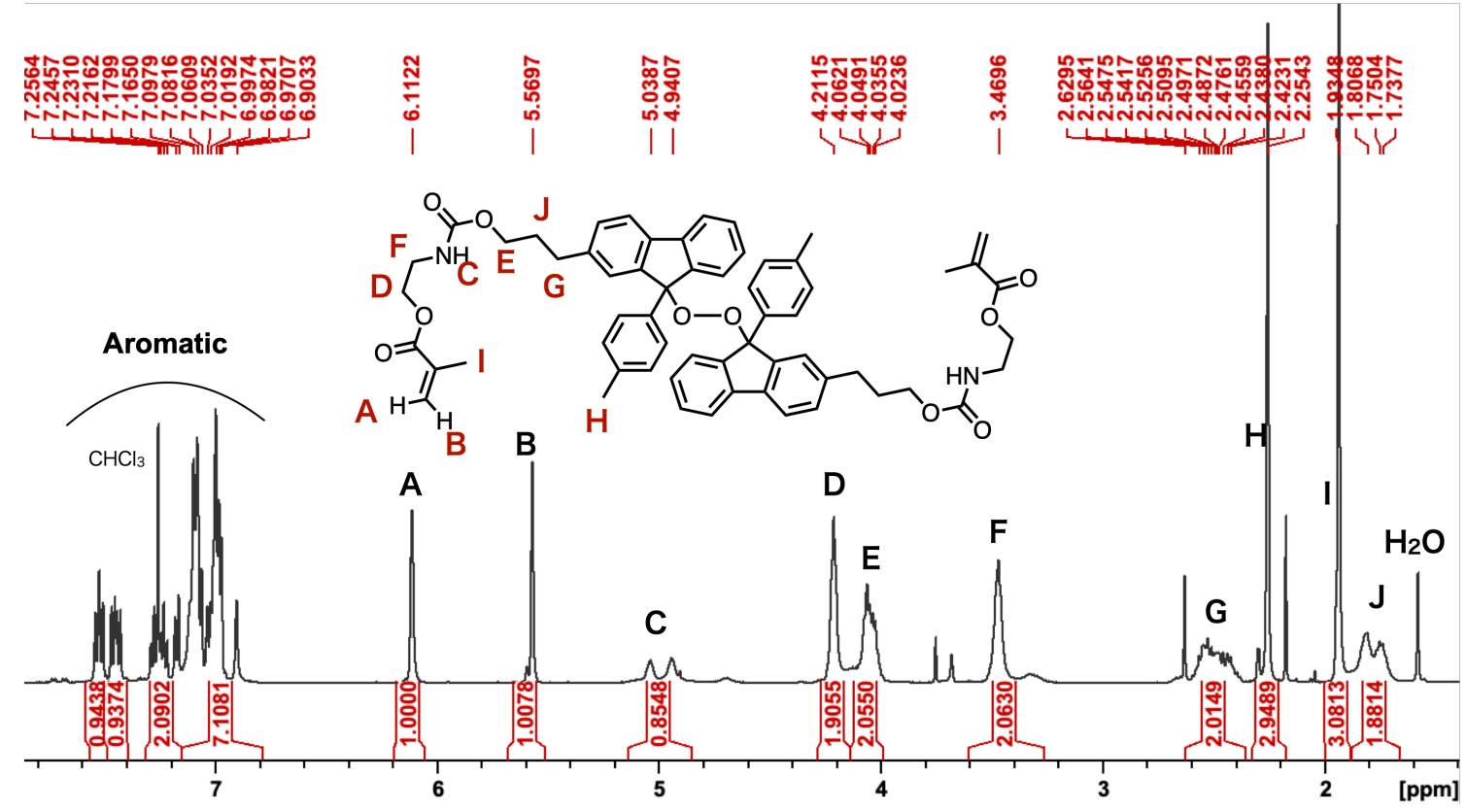

Figure S27. ${ }^{1} \mathrm{H}$ NMR spectrum of BMPF-2-VCL $\left(500 \mathrm{MHz}, \mathrm{CDCl}_{3}, 25^{\circ} \mathrm{C}\right)$.

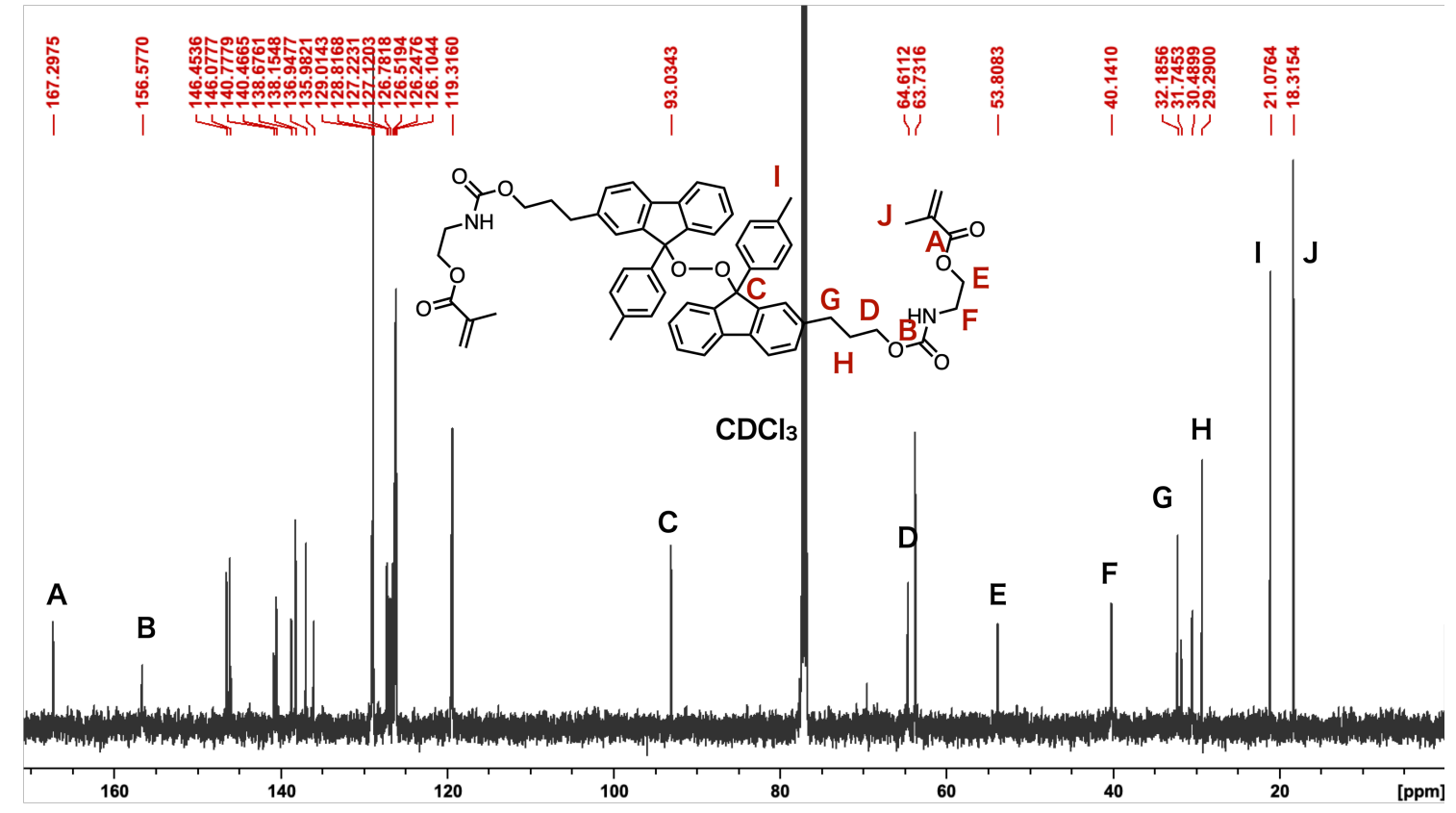

Figure S28. ${ }^{13} \mathrm{C}$ NMR spectrum of BMPF-2-VCL $\left(125 \mathrm{MHz}, \mathrm{CDCl}_{3}, 25^{\circ} \mathrm{C}\right)$. 


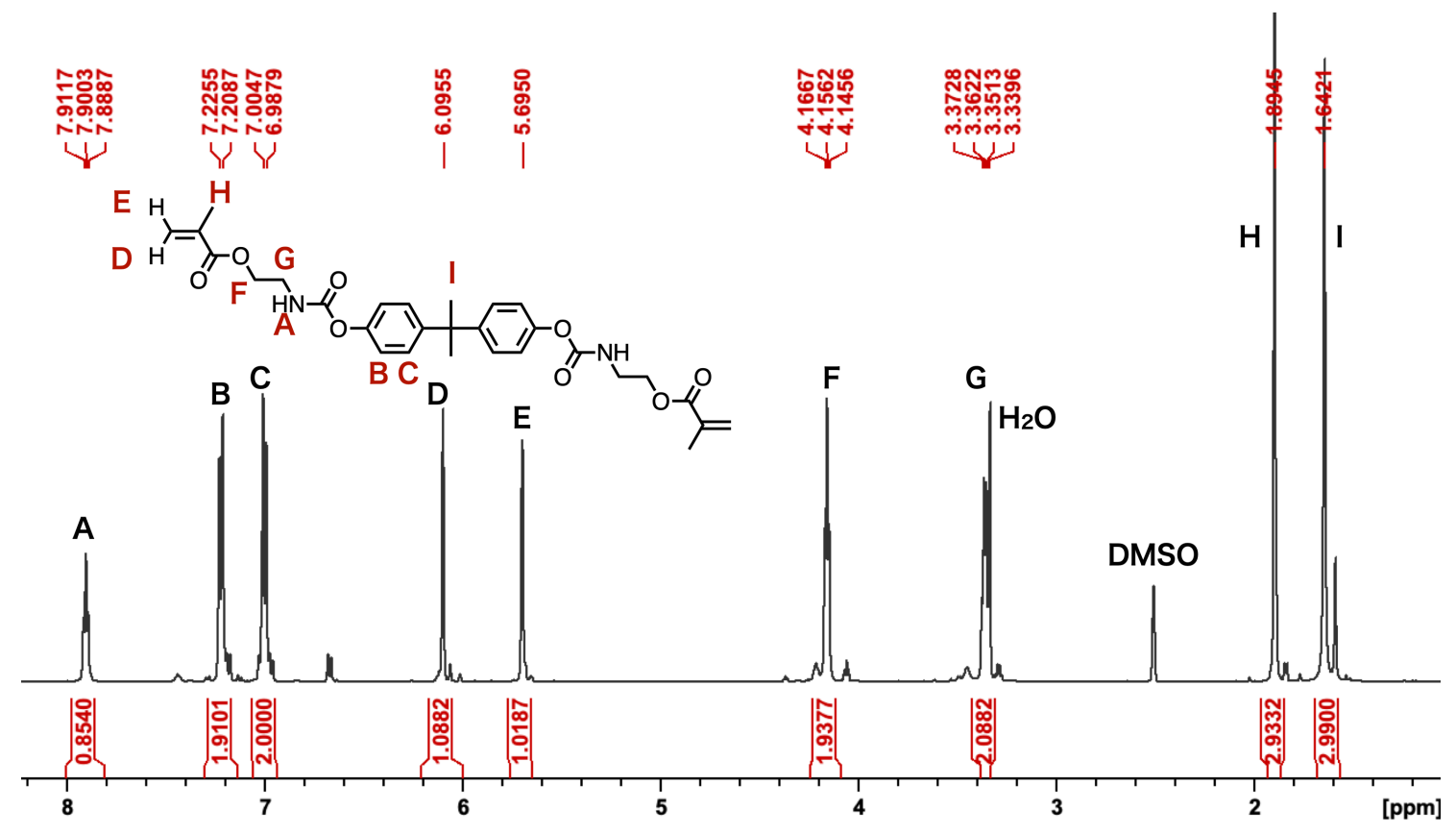

Figure S29. ${ }^{1} \mathrm{H}$ NMR spectrum of BPA-VCL $\left(500 \mathrm{MHz}\right.$, DMSO- $\left.d_{6}, 25^{\circ} \mathrm{C}\right)$

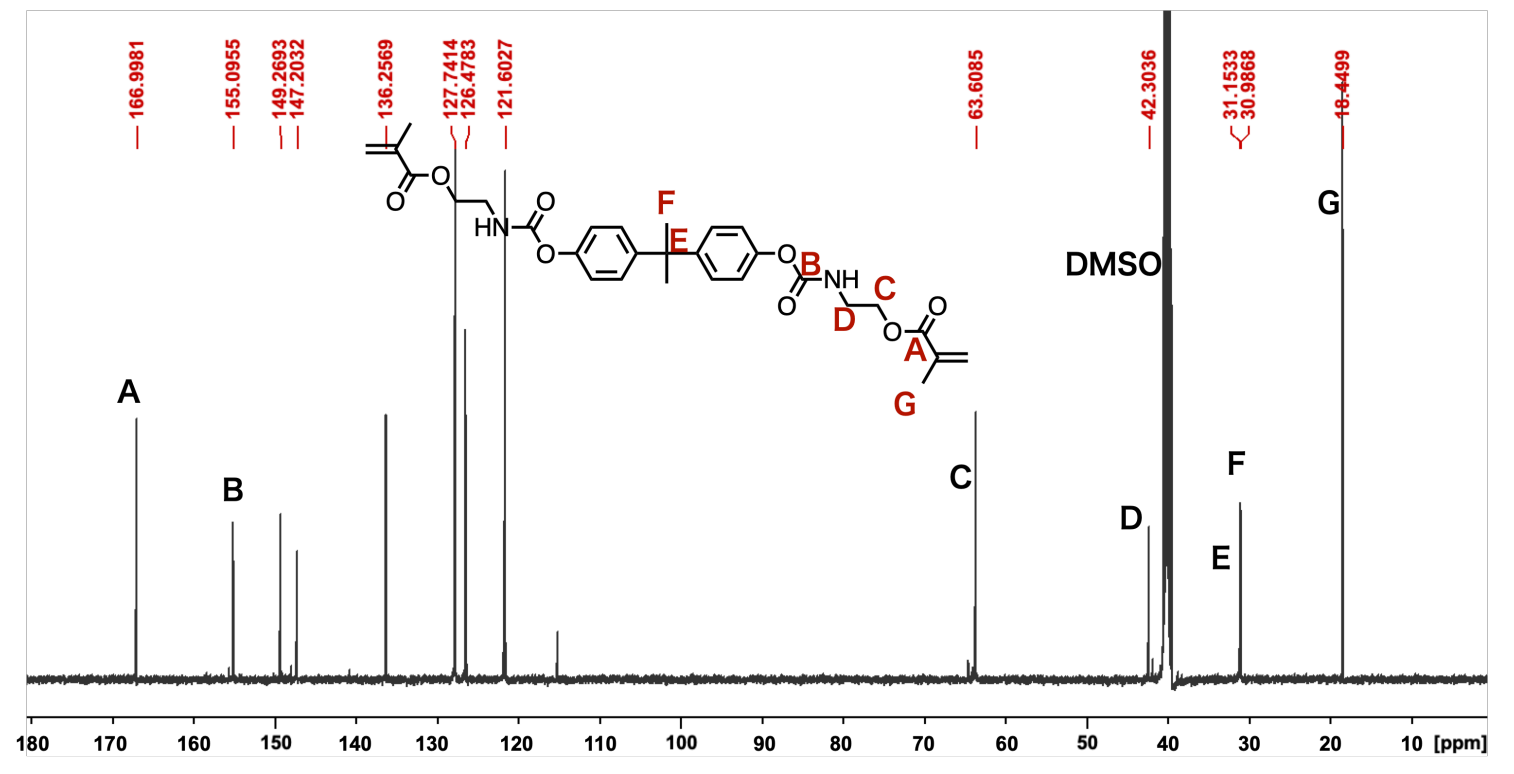

Figure S30. ${ }^{13} \mathrm{C}$ NMR spectrum of BPA-VCL $\left(125 \mathrm{MHz}\right.$, DMSO- $\left.d 6,25^{\circ} \mathrm{C}\right)$. 


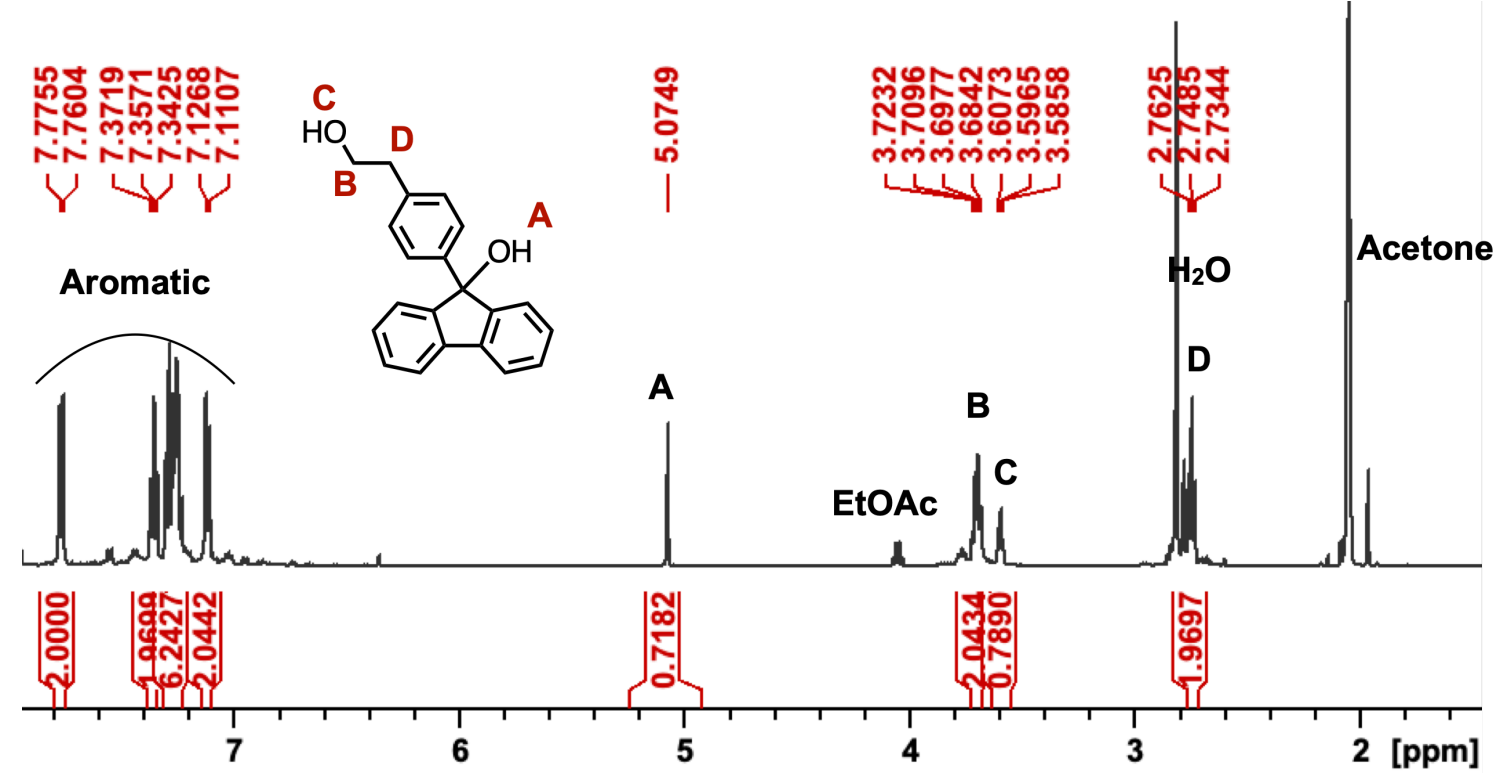

Figure S31. ${ }^{1} \mathrm{H}$ NMR spectrum of 9-aryl-9-fluorenol $\left(500 \mathrm{MHz}\right.$, acetone- $\left.d 6,25^{\circ} \mathrm{C}\right)$. 


\section{Computational detail}

10.1 General information

Density functional theory (DFT) calculations were performed using Gaussian 09 program package ${ }^{2}$. Geometry optimizations and vibrational analyses of all local equilibrium and transition state structures were performed using unrestricted B3LYP/6-31G(d). The energy diagram of the reaction pathway was obtained by the global reaction route mapping method (GRRM) $)^{3-10}$ based on Gaussian 09. All stationary points were optimized without any symmetry assumptions and were characterized by normal coordinate analysis at the same level of theory (number of imaginary frequencies, NIMAG, 0 for minima and 1 for transition states). The intrinsic reaction coordinate (IRC) method ${ }^{11-13}$ was used to track minimum energy paths from transition structures to the corresponding local minima. The stabilities of the wavefunction were confirmed by 'Stable' keyword. Cartesian coordinates and energies of the computed structures are listed in Section 9.2 as shown below.

10.2 Optimized geometries and cartesian coordination

The geometries were given by ball and stick type model (atom color: gray = carbon, red = oxygen, white $=$ hydrogen).

\section{MPF-1-OR}

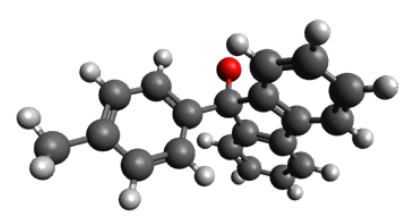

Energy: -846.335050699090 a.u.

Gibbs free energy: -846.093181511580 a.u.

Zero-point energy: 0.287780595130 a.u.

$\begin{array}{llll}\text { C } & 1.419358865463 & 3.488787067970 & -0.131242902052 \\ \mathrm{C} & 2.616110249773 & 3.020018180919 & -0.685883565019 \\ \mathrm{C} & 2.888470175663 & 1.651278710921 & -0.747399191198 \\ \mathrm{C} & 1.942720235495 & 0.755941723513 & -0.245153497375 \\ \mathrm{C} & 0.738455651866 & 1.232986215486 & 0.308406515351 \\ \mathrm{C} & 0.470727346900 & 2.593787744746 & 0.375972210530 \\ \mathrm{C} & 1.947248097880 & -0.709086696291 & -0.170340940663 \\ \mathrm{C} & 0.748725070653 & -1.139908388159 & 0.434466571497 \\ \mathrm{C} & -0.117298378570 & 0.074701660432 & 0.845805092537 \\ \mathrm{C} & 0.478768622987 & -2.485949079339 & 0.646654857020 \\ \mathrm{C} & 1.418475138934 & -3.425443741449 & 0.211946108323\end{array}$




\begin{tabular}{lrrr}
$\mathrm{C}$ & 2.606503798080 & -3.010071992860 & -0.402462331880 \\
$\mathrm{C}$ & 2.880430663353 & -1.653516523138 & -0.599264397973 \\
$\mathrm{C}$ & -1.555799457870 & 0.030011296199 & 0.332074650223 \\
$\mathrm{C}$ & -2.610077271494 & -0.189981529842 & 1.219899840336 \\
$\mathrm{C}$ & -3.926144886481 & -0.251732995064 & 0.755060863300 \\
$\mathrm{C}$ & -4.225019900290 & -0.097523454492 & -0.602105473816 \\
$\mathrm{C}$ & -3.157797498704 & 0.119548593423 & -1.487605684929 \\
$\mathrm{C}$ & -1.845055489409 & 0.185468245392 & -1.030603784366 \\
$\mathrm{C}$ & -5.649527291585 & -0.143569048955 & -1.104245145915 \\
$\mathrm{H}$ & -5.741492769538 & -0.776304072385 & -1.994920408121 \\
$\mathrm{H}$ & -6.008175506901 & 0.856256295356 & -1.382615174604 \\
$\mathrm{H}$ & -6.329747783293 & -0.535690661179 & -0.341364231286 \\
$\mathrm{H}$ & -3.360113989138 & 0.239299167615 & -2.550104589570 \\
$\mathrm{H}$ & -1.037766148095 & 0.357234990362 & -1.738302874595 \\
$\mathrm{H}$ & -2.391496451154 & -0.309870590708 & 2.275844796267 \\
$\mathrm{H}$ & -4.733985065162 & -0.422241396343 & 1.463678331992 \\
$\mathrm{H}$ & -0.446345206685 & -2.796608204934 & 1.122533962689 \\
$\mathrm{H}$ & 1.225358078919 & -4.485507802516 & 0.350070420381 \\
$\mathrm{H}$ & 3.326370918022 & -3.754042225881 & -0.732975232985 \\
$\mathrm{H}$ & -0.461193732999 & 2.955205252044 & 0.801641946675 \\
$\mathrm{H}$ & 1.224201454046 & 4.557139396902 & -0.097400322448 \\
$\mathrm{H}$ & 3.341362110649 & 3.729447711083 & -1.075255142147 \\
$\mathrm{H}$ & 3.820846301153 & 1.295804187934 & -1.178287536577 \\
$\mathrm{O}$ & 3.805925455702 & -1.344668739509 & -1.077990138661 \\
& -0.009771382782 & 0.021359458743 & 2.220085786540 \\
\hline
\end{tabular}

TS-A

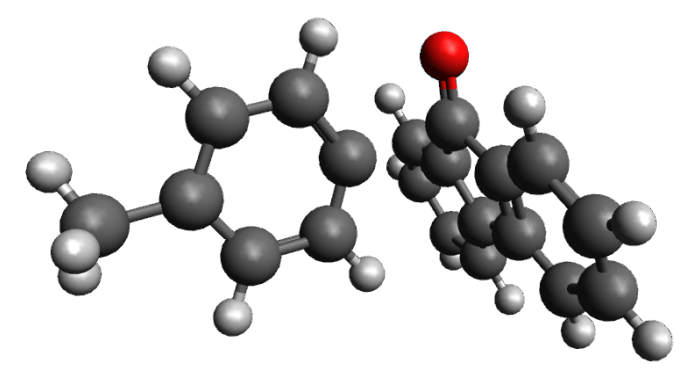

Energy: -846.306451373876 a.u.

Gibbs free energy: -846.069031567864 a.u.

Zero-point energy: 0.285197616063 a.u. 


\begin{tabular}{|c|c|c|c|}
\hline $\mathrm{C}$ & 1.417443558623 & 3.491854433162 & 0.030733361458 \\
\hline $\mathrm{C}$ & 2.266546902375 & 3.014943524783 & -0.974042938963 \\
\hline $\mathrm{C}$ & 2.442949937002 & 1.640751149625 & -1.177973612114 \\
\hline $\mathrm{C}$ & 1.748144659290 & 0.748778290155 & -0.363071886747 \\
\hline $\mathrm{C}$ & 0.884550151551 & 1.238008618806 & 0.636879451426 \\
\hline $\mathrm{C}$ & 0.716459687829 & 2.598548004928 & 0.849224622380 \\
\hline $\mathrm{C}$ & 1.758396647935 & -0.729523937914 & -0.302966460479 \\
\hline $\mathrm{C}$ & 0.900723929293 & -1.147855076837 & 0.733544733195 \\
\hline $\mathrm{C}$ & 0.283649175809 & 0.069729992954 & 1.386934722227 \\
\hline $\mathrm{C}$ & 0.752240481734 & -2.488840035460 & 1.056259535038 \\
\hline $\mathrm{C}$ & 1.466774137191 & -3.435655660274 & 0.313169071564 \\
\hline $\mathrm{C}$ & 2.309882478910 & -3.030140443497 & -0.727361088542 \\
\hline $\mathrm{C}$ & 2.466772897186 & -1.674741130254 & -1.042488398893 \\
\hline $\mathrm{C}$ & -1.570184634135 & 0.007519651229 & 0.360274620763 \\
\hline $\mathrm{C}$ & -2.668491366418 & -0.014902340109 & 1.190353774817 \\
\hline $\mathrm{C}$ & -3.924924029307 & -0.058744378532 & 0.570170271309 \\
\hline $\mathrm{C}$ & -4.051263880577 & -0.080098071398 & -0.824861437765 \\
\hline $\mathrm{C}$ & -2.885498933033 & -0.050367214055 & -1.604371871481 \\
\hline $\mathrm{C}$ & -1.614723811887 & -0.006375124449 & -1.017098522060 \\
\hline $\mathrm{C}$ & -5.412307020191 & -0.157702504345 & -1.478845079776 \\
\hline $\mathrm{H}$ & -5.686604935029 & -1.196527198570 & -1.705850858471 \\
\hline $\mathrm{H}$ & -5.436119951687 & 0.396886093275 & -2.423135945868 \\
\hline $\mathrm{H}$ & -6.192854022019 & 0.250197662734 & -0.828398476513 \\
\hline $\mathrm{H}$ & -2.963429753844 & -0.059439851173 & -2.689842973954 \\
\hline $\mathrm{H}$ & -0.718120641222 & 0.019587178737 & -1.627446939500 \\
\hline $\mathrm{H}$ & -2.560556177536 & 0.005206046478 & 2.268634936652 \\
\hline $\mathrm{H}$ & -4.818896071523 & -0.074169314548 & 1.190553673352 \\
\hline $\mathrm{H}$ & 0.094707040029 & -2.785466217510 & 1.868607438309 \\
\hline $\mathrm{H}$ & 1.368393505385 & -4.492614012044 & 0.545025604493 \\
\hline $\mathrm{H}$ & 2.857428504448 & -3.777400191307 & -1.295667395259 \\
\hline $\mathrm{H}$ & 0.054370831043 & 2.950702712497 & 1.635275379635 \\
\hline $\mathrm{H}$ & 1.303759610121 & 4.562674123867 & 0.175655377468 \\
\hline $\mathrm{H}$ & 2.803411433671 & 3.721174946560 & -1.601896694546 \\
\hline $\mathrm{H}$ & 3.118491981066 & 1.285097589687 & -1.951846061694 \\
\hline $\mathrm{H}$ & 3.138078637241 & -1.373575937473 & -1.842727235816 \\
\hline $\mathrm{O}$ & -0.167100959379 & 0.114468620217 & 2.553947304355 \\
\hline
\end{tabular}




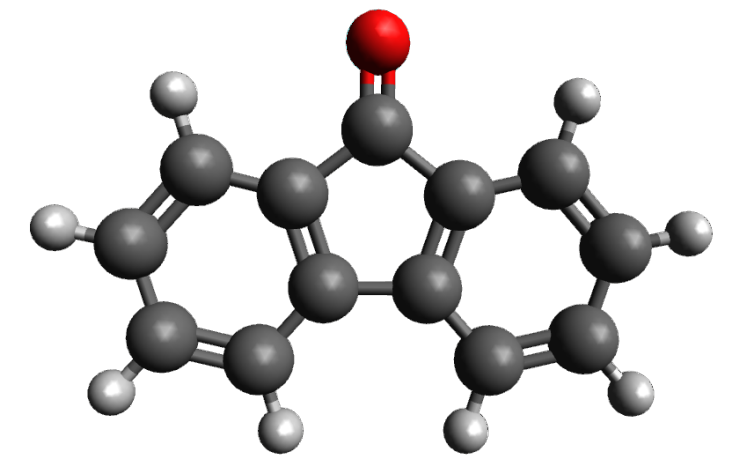

Energy: -575.437026269119 a.u.

Gibbs free energy: -575.301511171719 a.u.

Zero-point energy: 0.169967318734 a.u.

C

C

0.066043384068

3.468135037761

$-0.000000000019$

1.393910142838

3.031296028407

$-0.000000000012$

C

$-0.983053442142$

2.539147057183

$-0.000000000017$

C

$-0.665013857124$

1.189493156258

$-0.000000000012$

C

0.671687300077

0.74198632665

$-0.000000000012$

C

1.711501791166

1.664389309739

$-0.000000000009$

C

0.671687300075

$-0.741986326651$

0.000000000002

C

$-1.577552664161$

0.000000000001

0.000000000034

C

$-0.665013857127$

$-1.189493156258$

0.000000000005

C

1.711501791162

$-1.664389309738$

0.000000000021

C

1.393910142836

$-3.031296028406$

0.000000000004

C

0.066043384069

$-3.468135037759$

$-0.000000000022$

C

$-0.983053442142$

$-2.539147057183$

$-0.000000000023$

$\mathrm{H}$

$-2.022598511336$

$-2.854985143897$

$-0.000000000052$

$\mathrm{H}$

2.197179884372

$-3.763371163345$

0.000000000025

$\mathrm{H}$

$-0.150716300093$

$-4.532593145100$

$-0.000000000033$

$\mathrm{H}$

2.750385495522

$-1.345251054596$

0.000000000024

$\mathrm{H}$

2.750385495525

1.345251054595

0.000000000020

$\mathrm{H}$

$-2.022598511342$

2.854985143878

$-0.000000000007$

$\mathrm{H}$

$-0.150716300094$

4.53259314510

$-0.000000000017$

$\mathrm{H}$

2.197179884373

3.763371163347

$-0.000000000003$

$\mathrm{O}$

$-2.795959110525$

0.000000000013

0.000000000103 


\section{P-A (phenyl-radical)}

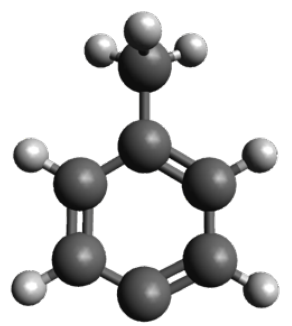

Energy: -270.878797479590 a.u.

Gibbs free energy: -270.794448961645 a.u.

Zero-point energy: 0.115230573880 a.u.

$\begin{array}{lrrr}\mathrm{C} & 0.129399400024 & -1.207072633439 & -0.009801119181 \\ \mathrm{C} & -1.273749395883 & -1.222519361510 & 0.001284745059 \\ \mathrm{C} & -1.908853026096 & -0.000292012613 & 0.009172948418 \\ \mathrm{C} & -1.274052822625 & 1.222102541401 & 0.004527641436 \\ \mathrm{C} & 0.129106857541 & 1.207027936933 & -0.006597275624 \\ \mathrm{C} & 0.843079093343 & 0.000071660758 & -0.010707020205 \\ \mathrm{H} & 0.672464579381 & -2.150527889341 & -0.019971116052 \\ \mathrm{H} & -1.818880648080 & -2.162810942000 & -0.001170118575 \\ \mathrm{H} & 0.671941552317 & 2.150638310906 & -0.014263115371 \\ \mathrm{H} & -1.819411703125 & 2.162265295554 & 0.004564935356 \\ \mathrm{C} & 2.355664207466 & 0.000211475417 & 0.009203188906 \\ \mathrm{H} & 2.741970597918 & -0.001894065645 & 1.037274124542 \\ \mathrm{H} & 2.763281108238 & 0.886726773465 & -0.488198660425 \\ \mathrm{H} & 2.763500199580 & -0.884127089886 & -0.491889158283\end{array}$

TS-B

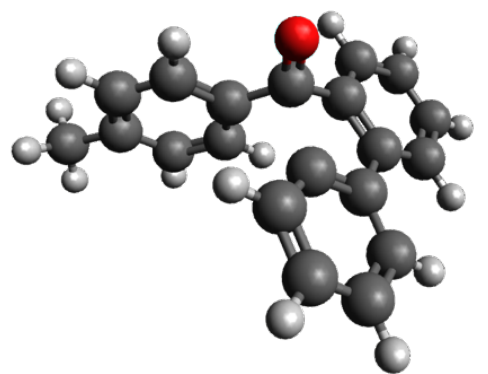

Energy: -846.307395355816 a.u.

Gibbs free energy: -846.067943526685 a.u.

Zero-point energy: 0.285600173003 a.u. 


\begin{tabular}{|c|c|c|c|}
\hline $\mathrm{C}$ & 1.874578508935 & 3.551672732472 & -0.191528728315 \\
\hline $\mathrm{C}$ & 2.892773995295 & 2.917359611700 & -0.907551595186 \\
\hline $\mathrm{C}$ & 2.960742186551 & 1.525173059557 & -0.948178186078 \\
\hline $\mathrm{C}$ & 2.003721009009 & 0.758184319912 & -0.274628711748 \\
\hline $\mathrm{C}$ & 0.972194024086 & 1.399487802254 & 0.437963831318 \\
\hline $\mathrm{C}$ & 0.916201725794 & 2.791940862367 & 0.483824938480 \\
\hline $\mathrm{C}$ & 1.965912636213 & -0.710149993252 & -0.205466044854 \\
\hline $\mathrm{C}$ & 0.957046342835 & -1.249048096106 & 0.574588456666 \\
\hline $\mathrm{C}$ & -0.041773768989 & 0.5567668661748 & 1.206789179800 \\
\hline $\mathrm{C}$ & 0.720465916470 & -2.575660522281 & 0.823325943054 \\
\hline $\mathrm{C}$ & 1.592382724450 & -3.480495267745 & 0.192904461301 \\
\hline $\mathrm{C}$ & 2.626854072169 & -3.007914080915 & -0.621495730378 \\
\hline $\mathrm{C}$ & 2.819768296601 & -1.639403819680 & -0.825450604563 \\
\hline $\mathrm{C}$ & -1.374299752427 & 0.275926647624 & 0.552684277373 \\
\hline $\mathrm{C}$ & -2.414105863340 & -0.231286254781 & 1.345496110438 \\
\hline $\mathrm{C}$ & -3.663381722277 & -0.486662389919 & 0.791704748864 \\
\hline $\mathrm{C}$ & -3.918097743312 & -0.243378774798 & -0.567379001412 \\
\hline $\mathrm{C}$ & -2.8738886661103 & 0.261674110577 & -1.352796328316 \\
\hline $\mathrm{C}$ & -1.618954499665 & 0.520680516722 & -0.804761186192 \\
\hline $\mathrm{C}$ & -5.286182887360 & -0.494114371792 & -1.155574801240 \\
\hline $\mathrm{H}$ & -5.748667964193 & -1.390399446078 & -0.727483360484 \\
\hline $\mathrm{H}$ & -5.239054927166 & -0.621971656289 & -2.241904695126 \\
\hline $\mathrm{H}$ & -5.964507918347 & 0.346002019629 & -0.954149537554 \\
\hline $\mathrm{H}$ & -3.045933326087 & 0.455743819965 & -2.409157612940 \\
\hline $\mathrm{H}$ & -0.826956198385 & 0.912849738756 & -1.435716182541 \\
\hline $\mathrm{H}$ & -2.2198768866567 & -0.411542966634 & 2.398095899552 \\
\hline $\mathrm{H}$ & -4.459405659410 & -0.878696145937 & 1.421468812044 \\
\hline $\mathrm{H}$ & -0.091960653403 & -2.912858392222 & 1.459985476000 \\
\hline $\mathrm{H}$ & 1.458420894150 & -4.548874342807 & 0.341854122267 \\
\hline $\mathrm{H}$ & 3.294768529610 & -3.716632680330 & -1.103054811817 \\
\hline $\mathrm{H}$ & 0.125162049595 & 3.282029858625 & 1.044903328891 \\
\hline $\mathrm{H}$ & 1.827334966969 & 4.636595503768 & -0.156834928456 \\
\hline $\mathrm{H}$ & 3.638616949443 & 3.508648120876 & -1.431737772214 \\
\hline $\mathrm{H}$ & 3.762400949575 & 1.039292356080 & -1.497676619620 \\
\hline $\mathrm{H}$ & 3.632476320494 & -1.295738321407 & -1.460770828717 \\
\hline $\mathrm{O}$ & 0.078166333784 & 0.461029580341 & 2.447827681702 \\
\hline
\end{tabular}




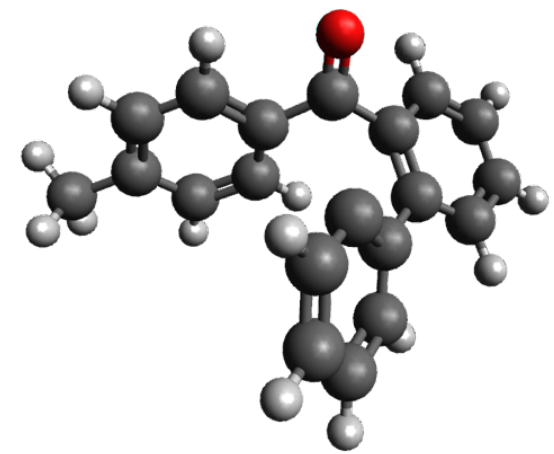

Energy: -846.314485659094 a.u.

Gibbs free energy: -846.075587817838 a.u.

Zero-point energy: 0.28681692660 a.u.

\begin{tabular}{|c|c|c|}
\hline 2.333892474029 & 3.534706664528 & -0.030749011545 \\
\hline 3.173554161205 & 2.704999274376 & -0.775163883131 \\
\hline 2.932801586048 & 1.334329149977 & -0.820257985479 \\
\hline 1.838421787417 & 0.758970438227 & -0.152218103385 \\
\hline 0.979133936503 & 1.608157050666 & 0.581954250856 \\
\hline 1.254815637874 & 2.980230986430 & 0.652812064350 \\
\hline 1.658078556273 & -0.714444845281 & -0.175490605164 \\
\hline 1.171481889067 & -1.424740142988 & 0.909803906259 \\
\hline-0.237899100035 & 1.140273188732 & 1.349168929332 \\
\hline 1.009199922156 & -2.786106859435 & 1.000971818278 \\
\hline 1.367415730335 & -3.540853672368 & -0.127481025176 \\
\hline 1.856241929766 & -2.893501163641 & -1.265625528881 \\
\hline 1.999416910583 & -1.506080053527 & -1.294698370989 \\
\hline-1.384979121663 & 0.513947773477 & 0.621193695167 \\
\hline-2.433150758678 & -0.034711203773 & 1.378039493877 \\
\hline-3.543658690187 & -0.584358858616 & 0.751585497441 \\
\hline-3.653017679799 & -0.595761504879 & -0.649064767376 \\
\hline-2.612730593039 & -0.031985305317 & -1.397892780924 \\
\hline-1.491006117247 & 0.513200085988 & -0.775822025022 \\
\hline-4.853858114015 & -1.214695967088 & -1.323133254103 \\
\hline-5.783702533477 & -0.949861155241 & -0.807159727973 \\
\hline-4.786180707091 & -2.310815531653 & -1.321503299808 \\
\hline-4.939962621493 & -0.892751657246 & -2.365739373805 \\
\hline-2.682980431113 & -0.017518065904 & -2.483055118834 \\
\hline
\end{tabular}




$\begin{array}{lrrr}\mathrm{H} & -0.702093484073 & 0.950243580279 & -1.379664996923 \\ \mathrm{H} & -2.353550139801 & -0.012778918066 & 2.460141493800 \\ \mathrm{H} & -4.345029961177 & -1.008939221034 & 1.352553378225 \\ \mathrm{H} & 0.624744762126 & -3.262666194523 & 1.898698714175 \\ \mathrm{H} & 1.259860348931 & -4.622687809283 & -0.113439701285 \\ \mathrm{H} & 2.122675567128 & -3.474998179222 & -2.143931552802 \\ \mathrm{H} & 0.600997261246 & 3.610374533098 & 1.248406293298 \\ \mathrm{H} & 2.523588450221 & 4.602927686410 & 0.025756277742 \\ \mathrm{H} & 4.028837573935 & 3.119720558055 & -1.301794082562 \\ \mathrm{H} & 3.625260837683 & 0.687780783888 & -1.351322813122 \\ \mathrm{H} & 2.360772733816 & -1.021318837492 & -2.198524988354 \\ \mathrm{O} & -0.310291892205 & 1.375451207440 & 2.549189293256\end{array}$




\section{References}

(1) Shen, X.; Gu, N.; Liu, P.; Ma, X.; Xie, J.; Liu, Y.; He, L.; Dai, B. A Simple and Efficient Synthesis of 9-Arylfluorenes via Metal-Free Reductive Coupling of Arylboronic Acids and NTosylhydrazones in Situ. RSC Adv. 2015, 5 (78), 63726-63731.

(2) Gaussian 09, Revision D.1, Frisch, M. J., Trucks, G. W., Schlegel, H. B., Scuseria, G. E., Robb, M. A., Cheeseman, J. R., Scalmani, G., Barone, V., Mennucci, B., Petersson, G. A., Nakatsuji, H., Caricato, M., Li, X., Hratchian, H. P., Izmaylov, A. F., Bloino, J., Zheng, G., Sonnenberg, J. L., Hada, M., Ehara, M., Toyota, K., Fukuda, R., Hasegawa, J., Ishida, M., Nakajima, T., Honda, Y., Kitao, O., Nakai, H., Vreven, T., Montgomery Jr., J. A., Peralta, J. E., Ogliaro, F., Bearpark, M., Heyd, J. J., Brothers, E., Kudin, K. N., Staroverov, V. N., Kobayashi, R., Normand, J., Raghavachari, K., Rendell, A., Burant, J. C., Iyengar, S. S., Tomasi, J., Cossi, M., Rega, N., Millam, J. M., Klene, M., Knox, J. E., Cross, J. B., Bakken, V., Adamo, C., Jaramillo, J., Gomperts, R., Stratmann, R. E., Yazyev, O., Austin, A. J., Cammi, R., Pomelli, C., Ochterski, J. W., Martin, R. L., Morokuma, K., Zakrzewski, V. G., Voth, G. A., Salvador, P., Dannenberg, J. J., Dapprich, S., Daniels, A. D., Farkas, Ö., Foresman, J. B., Ortiz, J. V., Cioslowski, J. and Fox, D. J. Gaussian, Inc., Wallingford CT (2010).

(3) Ohno, K. and Maeda, S. A scaled hypersphere search method for the topography of reaction pathways on the potential energy surface. Chem. Phys. Lett. 2004, 384 (4-6), 277-282.

(4) Maeda, S. and Ohno, K. Energy Surfaces by the Scaled Hypersphere Search Method: Applications to ab Initio Surfaces of Formaldehyde and Propyne Molecules. J. Phys. Chem. A 2005, 109 (25), $5742-5753$.

(5) Yang, X.; Maeda, S. and Ohno, K. Global Investigation on the Potential Energy Surface of $\mathrm{CH}_{3} \mathrm{CN}$ : Application of the Scaled Hypersphere Search Method. J. Phys. Chem. A 2005, 109 (32), 73197328.

(6) Ohno, K. and Maeda, S. Global Reaction Route Mapping on Potential Energy Surfaces of Formaldehyde, Formic Acid, and Their Metal-Substituted Analogues. J. Phys. Chem. A 2006, 110 (28), 8933-8941.

(7) Yang, X.; Maeda, S. and Ohno, K. Global analysis of reaction pathways on the potential energy surface of cyanoacetylene by the scaled hypersphere search method. Chem. Phys. Lett. 2006, $418(1-3), 208-216$.

(8) Maeda, S. and Ohno, K. Structures of Water Octamers $\left(\mathrm{H}_{2} \mathrm{O}\right)_{8}$ : Exploration on Ab Initio Potential Energy Surfaces by the Scaled Hypersphere Search Method. J. Phys. Chem. A 2007, 111 (20), $4527-4534$.

(9) Yang, X.; Maeda, S. and Ohno, K. Global Mapping of Equilibrium and Transition Structures on Potential Energy Surfaces by the Scaled Hypersphere Search Method: Applications to ab Initio Surfaces of Formaldehyde and Propyne Molecules. J. Phys. Chem. A 2007, 111 (25), 
$5099-5110$

(10) Watanabe, Y.; Maeda, S. and Ohno, K. Global reaction route mapping on potential energy surfacesof $\mathrm{C}_{2} \mathrm{H}_{7}^{+}$and $\mathrm{C}_{3} \mathrm{H}_{9}{ }^{+}$. Chem. Phys. Lett. 2007, 447 (1-3), 21-26.

(11) Fukui, K. The Path of Chemical Reactions - The IRC Approach. Acc. Chem. Res. 1981, 14 (12), $363-368$.

(12) Ishida, K.; Morokuma, K., and Komornicki, A. The intrinsic reaction coordinate. An ab initio calculation for $\mathrm{HNC} \rightarrow \mathrm{HCN}$ and $\mathrm{H}^{-}+\mathrm{CH}_{4} \rightarrow \mathrm{CH}_{4}+\mathrm{H}^{-}$. J. Chem. Phys. 1977, 66, 2153-2156.

(13) Gonzalez, C. and Schlegel, H. B. An improved algorithm for reaction path following. J. Chem. Phys. 1989, 90, 2154-2161. 